Fatty acid composition in the white muscle of Cottoidei fishes of Lake Baikal reflects their habitat depth

Radnaeva, Larisa D.

$2017-12$

Radnaeva, L D , Popov, D V , Grahl-Nielsen , O , Khanaev , I V , Bazarsadueva, S V \& Kakela , R 2017 , ' Fatty acid composition in the white muscle of Cottoidei fishes of Lake Baikal reflects their habitat depth ' , Environmental Biology of Fishes , vol. 100 , no. 12 , pp. 1623-1641 . https://doi.org/10.1007/s10641-017-0670-6

http://hdl.handle.net/10138/310741

https://doi.org/10.1007/s10641-017-0670-6

unspecified

acceptedVersion

Downloaded from Helda, University of Helsinki institutional repository.

This is an electronic reprint of the original article.

This reprint may differ from the original in pagination and typographic detail.

Please cite the original version. 


\section{Environmental Biology of Fishes \\ Fatty acid composition in the white muscle of Cottoidei fishes of Lake Baikal reflects their habitat depth \\ --Manuscript Draft--}

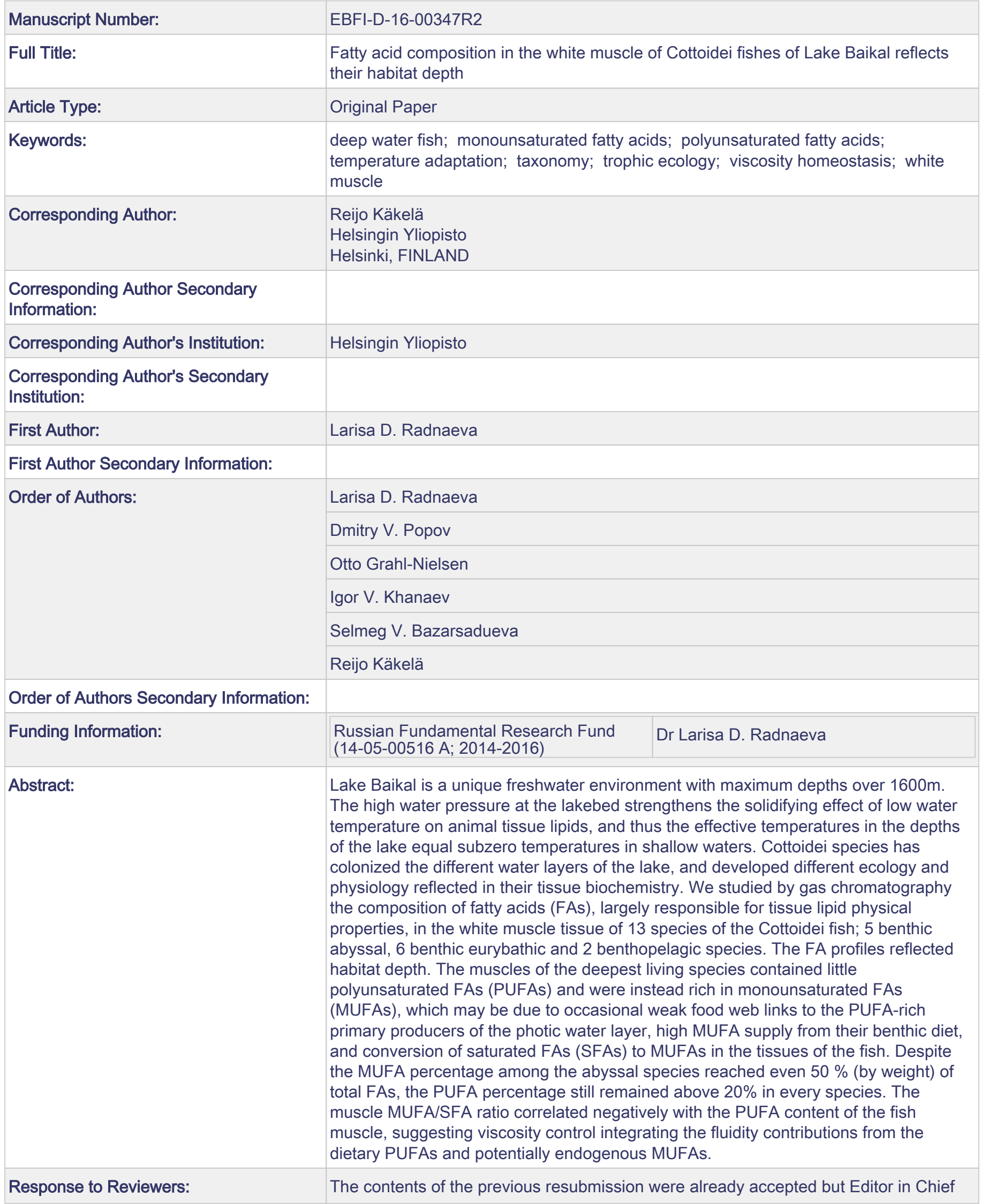


explained to us that Environmental Biology of Fishes does not allow any changes in authorship of manuscript after initial submission. Thus, as the only additional change to the manuscript, we were asked to remove the new author Melissa Westberg from the author list and include mention of assistance from her in the Acknowledgements. In this new version we have followed these instructions, and hope that our manuscript is now suitable for publication in the Journal. Since this is a small and easy-to-find change, we are submitting only the unamarked word-file of the manuscript texts and tables (with the previous Figure file). 
1

2

3

4

5

9

6

7

9

\section{Fatty acid composition in the white muscle of Cottoidei}

\section{fishes of Lake Baikal reflects their habitat depth}

8 Khanaev $^{4}$, Selmeg V. Bazarsadueva ${ }^{1,2}$, Reijo Käkelä ${ }^{*}$

${ }^{1}$ Baikal Institute of Nature Management SB RAS, Ulan-Ude, Russia

${ }^{2}$ Buryat State University, Ulan-Ude, Russia

${ }^{3}$ University of Bergen, Bergen, Norway

${ }^{4}$ Limnological Institute SB RAS, Irkutsk, Russia

${ }^{5}$ Department of Biosciences, University of Helsinki, Finland

Running head: Fatty acids in Cottoidei fishes of Lake Baikal

\section{* Corresponding authors:}

Larisa Radnaeva

Ulan-Ude, Russia

radld@mail.ru

Reijo Käkelä (contact during the review process) reijo.kakela@helsinki.fi

Phone +358504486506

Larisa D. Radnaeva ${ }^{1,2^{*}}$, Dmitry V. Popov ${ }^{1,2}$, Otto Grahl-Nielsen ${ }^{3}$, Igor V.

Keywords: Deep water fish, Monounsaturated fatty acids, Polyunsaturated fatty acids, Temperature adaptation, Taxonomy, Trophic ecology, Viscosity homeostasis, White muscle

Baikal Institute of Nature Management, Siberian Branch of Russian Academy of Science,

Department of Biosciences, PO BOX 65, 00014 University of Helsinki, Finland 
Abstract Lake Baikal is a unique freshwater environment with maximum depths over $1600 \mathrm{~m}$. The high water pressure at the lakebed strengthens the solidifying effect of low water temperature on animal tissue lipids, and thus the effective temperatures in the depths of the lake equal subzero temperatures in shallow waters. Cottoidei species has colonized the different water layers of the lake, and developed different ecology and physiology reflected in their tissue biochemistry. We studied by gas chromatography the composition of fatty acids (FAs), largely responsible for tissue lipid physical properties, in the white muscle tissue of 13 species of the Cottoidei fish; 5 benthic abyssal, 6 benthic eurybathic and 2 benthopelagic species. The FA profiles reflected habitat depth. The muscles of the deepest living species contained little polyunsaturated FAs (PUFAs) and were instead rich in monounsaturated FAs (MUFAs), which may be due to occasional weak food web links to the PUFA-rich primary producers of the photic water layer, high MUFA supply from their benthic diet, and conversion of saturated FAs (SFAs) to MUFAs in the tissues of the fish. Despite the MUFA percentage among the abyssal species reached even $50 \%$ (by weight) of total FAs, the PUFA percentage still remained above $20 \%$ in every species. The muscle MUFA/SFA ratio correlated negatively with the PUFA content of the fish muscle, suggesting viscosity control integrating the fluidity contributions from the dietary PUFAs and potentially endogenous MUFAs. 


\section{Introduction}

Lake Baikal is a relatively pristine rift lake with the depth and temperatures common to ocean deep-sea areas. Seasonal fluctuations of water temperature cease below $300 \mathrm{~m}$ and at the max depth of $\sim 1640 \mathrm{~m}$, the pressure is 164 atmospheres and temperature close to $0^{\circ} \mathrm{C}$. The average annual temperature in the open lake is $3^{\circ} \mathrm{C}$. Baikal is the world's most ancient freshwater lake (formed 20-25 million years ago), and its Fauna including diverse fish is largely endemic. The abyssal communities of fish and other organisms of the lake have been adapted to the high pressure, low temperature and scattered dietary sources, but very little comparative biochemistry has been conducted on them. During this century, a rapid climate change is expected to happen in the Baikal region, and when the duration of ice cover and its transparency are decreased the spring bloom of diatoms occurring under the ice is harmed (Semovski et al. 2000; Moore et al. 2009). The spring ice is an essential seat sustaining this rich bloom, which nourishes not only pelagic but also benthic animals. The rapidly sinking diatom mass is an important food resource for benthic animal communities providing them with different fatty acids (FAs) (Shishlyannikov et al. 2014). In addition, the increasing eutrophication, starting from the shore line and deltas, will finally affect benthic community structure and biomass of the deep parts of the lake (Chandra et al. 2005). At the same time, vertical migrations of cold-water stenothermal fish are likely affected since these species avoid entering the warming waters of the photic zone because of the physiological and biochemical stress caused by elevated temperature. Thus the benthic fish communities of the lake will be facing changes in the quantity and quality of food sources accessible for them. It is of note that the Lake Baikal Fauna is land locked with limited possibilities to migrate and find new habitats with optimal thermal conditions and suitable food resources, and therefore the expected changes due to climate change in the fish communities of Lake Baikal may be more pronounced and faster than the changes in the fish communities of polar sea areas.

Comparative and experimental works with deep-sea fish have shown that the tissues of the deepest living fish have the lowest activities of metabolic enzymes and oxygen consumption. To maintain some metabolism, they require compensatory adjustment of cell membrane fluidity, which provides integral membrane proteins conformational freedom needed for optimal function. Indeed, when the interspecies fluidity comparisons are carried out at room temperature and normal pressure, the membranes of the deep-living fish are the most fluid (Somero 1992; Sebert 2002). This is due to compensatory biochemical mechanisms, and without them the high pressure and low temperature of the natural habitat 
would make their lipid membranes too viscous. In near $0^{\circ} \mathrm{C}$ water, the additional membrane solidifying effect due to the pressure of 160 atm is equal to decreasing the temperature further by approximately $3^{\circ} \mathrm{C}$ (Macdonald 1984; Cossins and Macdonald 1989). Thus the challenge equals to maintaining the lipid viscosity homeostasis in subzero surface water. Structural modifications of membrane lipids are acknowledged to play a central role in the thermal adaptation of poikilotherm tissues, and the physical properties of the lipids are largely determined by their fatty acid (FA) composition (Hazel 1995; Käkelä et al. 2008). To achieve enhanced membrane fluidity poikilotherms can utilize diet-derived unsaturated FAs or increase the degree of their FA unsaturation by inserting new double bonds into the existing acyl chains by using desaturase enzymes (Trueman et al. 2000; Hsieh et al. 2007). The FA chain length also affects fluidity, but in lesser degree that the double bond content. The dietary supply of different FAs to be used for tissue lipids differs when entering from the pelagic photic water layers to the benthic abyssal zone, where also the abundance of food may have large spatial and temporal variability (Bühring and Christiansen 2001). Unfortunately, the Baikalian species studied for FAs are few, and information e.g. on true abyssal fish species, which from the perspective of environmental adaptation are among the most interesting ones, is mostly missing, giving this far little opportunities for ecophysiological interpretations (Morris 1984; Kozlova and Khotimchenko 1993; Kozlova and Khotimchenko 2000; Grahl-Nielsen et al. 2011; Averina et al. 2011).

First, Morris (1984) determined FA composition of some of the most common Baikalian species of copepods, gammarids and turbellarians and two endemic species of fish, large and small golomyanka (Comephorus baikalensis and $C$. dybowskii). The FA composition of these two fish species, having the habit of moving throughout the entire water column, was also determined in later investigations (Kozlova and Khotimchenko 2000). In addition, data on FA composition for Cottocomephorus (Kozlova and Khotimchenko 1993) and Coregonus (Ju et al. 1997) species of fish and also for some sponges, mollusks and amphipods are available (Dembitsky et al. 1994b,c; Bazarsadueva and Radnaeva 2013). Previously we have determined the FA composition in the tissues of 13 species or ecoforms of Lake Baikal fish (Grahl-Nielsen et al. 2011). The studies so far, focusing on the species inhabiting shallow waters or the upper half of the water column, have shown that the fish of the lake have species-specific FA compositions, which in general are characterized by high proportions of n-3 polyunsaturated FAs (n-3 PUFAs) but have at the same time high levels of n-6 PUFAs, resulting in a low n-3/n-6 ratio, characteristic for freshwater fish (Ackman 1967).

We got the opportunity to collect samples of several Cottoidei fishes by using deepsea trawling and manned submersibles (Table 1). These fish included 9 species from the 
Abyssocottidae family, which belonged to 2 ecological groups - benthic abyssal and benthic eurybathic fish, both groups mainly dwelling at deep depths, 400-1600 m Additional species sampled belonged to the Cottidae family; one abyssal and one eurybathic species from the genus of Batrachocottus and two benthopelagic species from the genus Cottocomephorus. The origin and evolution of these Cottoidei fishes is connected with the geohistory of the Baikal rift zone and global and regional climate change. About 2 million years ago, decreasing temperatures of the Quaternary period led to the extinction of the Tertiary fauna and created favorable conditions for cold water fishes. According to Dorogostaisky (1923) and Taliev (1955), ancestral forms of Cottoidei fish of the North Pacific penetrated the early Lake Baikal and began adaptive radiation, which led to the emergence of endemic species, genera, and possibly families (Fig. 1). Alternative views of the Cottoidei fishes originating from the Miocene period have also been presented (Berg 1922; Sideleva 1993). Since the invasion of the lake the early Cottoidei fishes specified and inhabited a wide range of depths.

With increasing depth of the Baikal water column, there is a reduction in fish diversity, number and biomass. The abyssal zone of the lake, with depths below $300 \mathrm{~m}$, is inhabited only by endemic Cottoidei species, which have no air bladder. The highest species richness, $12-15$ species, is found at the depth of $500-700 \mathrm{~m}$. At the depths of over $1000 \mathrm{~m}$, the number of species is 5-6, and at maximum depths usually only 3 species, namely Cottinella boulengeri, Abyssocottus gibbosus and Abyssocottus korotneffi, are found. Fishes in the abyssal zone are divided into truly abyssal species, which are exclusively dwelling at great depths but during ice cover may visit upper waters, and eurybathic species, which frequently migrate and feed over a wide range of depths (as examples abyssal Batrachocottus species and eurybathic Limnocottus griseus in Fig. 2). During winter months the eurybathic species are often found in the upper water but when ice melts and the temperature of the upper water rises they also prefer staying in the deeper parts of their habitat. In general, gammarids and debris are the base of the diet of true abyssal species. The importance of amphipods and variability of the diet is larger in the diet of eurybathic species. The species that on daily basis swim and feed at the bottom as well as in midwaters or even near the surface are called benthopelagic. Bentopelagic species mainly consume planktonic animals (e.g. Epishura baicalensis and Macrohectopus branickii). All abyssal Cottoidei fish are characterized by 147 elongated period of spawning at the constantly low water temperature. The spawning lasts from 2 to 4 months, and depending on the species it occurs in late autumn, mid-winter or even late spring but not reported in July-September. The males are guarding the clutches of eggs during their development (Fig. 2C). The habitat, diet and spawning time, if known, are listed by species in Table 2 . 
In this study we performed so far the most comprehensive comparison of the FA composition in the muscle tissue of the Cottoidei fish of Lake Baikal. It was hypothesized that the muscle FA composition may reflect the foraging ecology of the species i.e. supply of different dietary FAs available in the habitats, but the composition may also be affected by adaptive metabolic differences, i.e. the ability to endogenously synthesize low-melting FAs. The metabolism of different FAs in fish tissues and the potential dietary sources of these FAs are described in Table 3. The general view of cold-adapted ectothermic animals is that their tissues contain high proportions of polyunsaturated FAs (PUFAs) in order to keep the lipid membranes semifluid, which provides optimal microenvironment for membrane proteins to function, and also to keep storage lipids fluid enough to be accessible for enzymes hydrolyzing them for energy (Hazel 1995; Werbrouck et al. 2016). Thus we hypothesized that if the true abyssal species during summer months (when they reside at the bottom and feed on benthic items) have weak connection to the PUFA-rich food webs of the upper water, their tissue lipids need to be maintained fluid by accumulating MUFAs, which can be dietary or synthesized de novo by the fish. If so, how large proportion of such MUFAs are needed at the bottom of Lake Baikal to compensate for the lack of PUFAs? Further if PUFAs are few, how low their proportions can go in the tissues of the fish without risking essential biological functions?

The species studied in this work had different habitat depths and represented a gradual shift in their foraging ecology, from the fishes largely supported by the pelagic photic food web to the fishes utilizing abyssal benthic food sources. This collection of fish studied allowed us to examine whether the habitat depth is reflected in the FA biochemistry of the fish living in this freshwater system with oceanic depths. If the benthic supply of PUFAs relies largely on the food items of the upper water layers, we should be able to see a gradual shift in tissue FA composition, from PUFA dominance in the benthopelagic species to MUFA dominance in the true abyssal species. Alternatively, the particle rain from the photic water layer and occasionally found carcasses or some invertebrates and vertebrates would provide sufficient amounts of PUFAs to the abyssal species to maintain similar tissue FA composition as found in the benthopelagic species. Finding a very large difference would mean that the changes in duration of ice cover affecting the plankton bloom and vertical temperature gradients limiting migration towards surface may alter the PUFA supply of the true abyssal species, especially, and in future cause survival challenge for them. 


\section{Materials and methods}

Field Sampling

The 13 species of Cottoidei fish were collected in July-August, outside the reported spawning season of the fish, from different locations of Lake Baikal by using either deep-sea trawling or manned submersibles "Mir-1" and "Mir-2" (The International research expedition "Mirs on Lake Baikal", 2008-2010) (Table 1). Due to the tedious catching procedure, all the individuals caught were included in this study (but a male Batrachocottus nikolskii still seen to be guarding eggs was left unharmed). The order of the Federal Agency of Fisheries No 283 sets no restrictions for sampling the fish at Lake Baikal and thereby the sampling was approved by the official authorities. The collected fish were stored at $-25^{\circ} \mathrm{C}$ for less than 7 days prior to laboratory analyses.

Sample derivatization

In laboratory, weighed samples of white muscle $(\sim 30-40 \mathrm{mg}$, skin was removed and subsamples of muscle were taken from both sides of the fish body and combined) were placed into $15 \mathrm{ml}$ glass tubes with $1 \mathrm{ml}$ of anhydrous methanol containing $2 \mathrm{M} \mathrm{HCl}$. The tubes were filled with argon, then securely closed, and heated for $2 \mathrm{~h}$ at $90^{\circ} \mathrm{C}$ for complete methanolysis (Meier et al. 2006). After cooling to room temperature, the tubes were opened and the methanol was evaporated down to about $0.5 \mathrm{ml}$ under a stream of nitrogen, and $0.5 \mathrm{ml}$ distilled water was added to reduce the solubility of the FA methyl esters (FAMEs) formed, which subsequently were extracted with $2 \times 1 \mathrm{ml}$ hexane.

Fatty acid analysis

One microliter of the combined hexane extracts were injected splitless (the split was opened after $4 \mathrm{~min}$ ) and chromatographed on a $25 \mathrm{~m} \times 0.25 \mathrm{~mm}$ (i.d.) fused silica column with polyethylene-glycol (PEG) as stationary phase with a thickness of $0.2 \mu \mathrm{m}$ (CP-WAX 52CB Chrompack). Helium at 20 psi was used as the mobile phase. The column was mounted in an Agilent 6890A gas chromatograph equipped with a mass-selective detector 5973N. The oven was programmed as follows: $90^{\circ} \mathrm{C}$ for $4 \mathrm{~min}, 30^{\circ} \mathrm{C} \mathrm{min}-1$ up to $165^{\circ} \mathrm{C}$, then $3{ }^{\circ} \mathrm{C} \min ^{-1}$ up to $225^{\circ} \mathrm{C}$, and kept isothermal at this final temperature for $10.5 \mathrm{~min}$ before cooling for the next run. 
The chromatographic peaks of the methyl ester derivatives were identified by retention

time and mass spectra (employing the spectra of the authentic standards and reference spectra published in the library of Christie, http://lipidlibrary.aocs.org/). For quantification and monitoring of the performance of the GC column, a standard mixture of 20 FAMEs (GLC reference standard 68D from Nu-Chek Prep, Elysian) was chromatographed for each tenth sample. Empirical response factors relative to 18:0 were computed for the FAMEs present in known amounts in the standard mixture. The response factors for each of the FAMEs not present in the standard mixture were estimated by comparison with the standard FAMEs which resembled them most closely in terms of chain length and number of double bonds. The areas of the FAME peaks were corrected with the response factors, and the relative amount of each FA in a sample was expressed as a percent of the sum of all FAs in the sample. These practices accounted for the differences in FID detector responses for different FA structures (Ackman 1992) and additionally monitored for the potential random variation in the detector responses of the equipment used. Altogether 36 FAs were detected, but many were present in levels close to the detection limit, and therefore would contribute more noise than real information to the data set. Thus, the comparisons of ecological groups of fish were based on the 13 major FAs.

Statistical analyses

Principal component analysis (PCA) in the software package Sirius 8.5 (Pattern Recognition Systems, Bergen, Norway) was used as multivariate statistical method to describe the compositional relationships of the fishes. The FA data used as loadings were arcsine transformed to improve normality, and subsequently standardized (deviations of each variable equalized) to prevent the variables with the largest numbers from dominating the analyses. Following the PCA, which described the compositional differences between the fishes from the three ecological groups (bentic abyssal, benthic eurybathic and benthopelagic), soft independent modeling of class analogy (SIMCA, available in Sirius 8.5) was used for pair wise testing of the statistical significance of the separation between these groups (Wold and Sjöström 1977) $(\mathrm{P}<0.05$ was regarded as significant). In addition, a membership plot (available in Sirius 8.5) was created. This analysis indicated the probability $(0-1)$ each individual belonged to the PCA-based models of the three ecological groups (weighting exponent 2 was used, details of the residual and distance calculations of this analyses are found in Sirius 8.5). Univariate comparisons of the percentages of FA structural categories (SFA, MUFA and PUFA), percentages of individual FAs, and specific FA ratios in 
257 the fish ecological groups were performed with arcsine transformed data by using the

Kruskal-Wallis $\mathrm{H}$ test for multiple comparisons in which the significance levels were adjusted by the Bonferroni correction to account for the inflation of type I error. Regression analysis for arcsine transformed percentage data was used to study whether the MUFA/SFA ratio (sum wt\% of all MUFAs divided by sum wt\% of all SFAs) of muscle lipids (which can be adjusted by fish endogenously by desaturase enzyme) correlated with diet-derived PUFA totals (i.e. exogenously acquired lipid fluidity). The regression plot however uses untransformed data points to express in understandable way the different alternative FA compositions meeting the criteria for functional tissue lipids of fish living at low temperature and high pressure.

\section{Results}

The differences in the FA composition of the muscles of the studied ecological groups of fish species were first visualized by PCA (Fig. 3a). The first principal component, PC1 explained as much as $43 \%$ of the total variation in the data, and placed the benthic abyssal fishes with high relative amounts of $16: 1 n-7,18: 1 n-9,18: 2 n-6,14: 0$ and 18:1n-7 on the left side of the plot. The benthic eurybathic and benthopelagic fishes tended to be located on the right with their high relative amounts of 22:6n-3, 18:0, 16:0, 20:4n-6 and 20:5n-3. The PC2 axis (14\%) separated benthic eurybathic and benthopelagic fishes from each other. On this axis, the muscle samples of the eurybathic fishes contained more 22:5n-6 and 20:4n-6, and those of the benthopelagic fishes more 22:5n-3 and 22:6n-3 (Fig. 3a). Based on SIMCA, the fatty acid compositions of the benthopelagic fishes differed statistically significantly $(\mathrm{P}<0.05)$ from the abyssal and eurybathic fishes (table insert of Fig. 3a). The FA compositions of the abyssal and eurybathic groups of fish did not differ. Following the PCA, a membership plot was created, which indicated the probability level each individual fish belonged to the PCA-based models of the three ecological groups (Fig. 3b). A total of 58 individual samples per 62 showed a probability (of being a member of its ecological group) higher than 0.5 . However, one half of the Batrachocottus nikolskii (1/2) and Asprocottus abyssalis (3/6) samples showed similar or higher similarity with another model.

The benthic abyssal fishes had significantly lower relative SFA contents than the benthic eurybathic or benthopelagic fishes (median $21 \%$ versus $25-26 \%, \mathrm{H}=21.6, \mathrm{P}<0.001$ ) (Fig. 4). The main individual SFA was 16:0, which was present in the abyssal species with a median of $14 \%$ (Table 4) and species means ranging 12-14\% (Table 5). The benthic 
eurybathic and benthopelagic fishes contained slightly more of 16:0, their medians being 18\% and species means ranging 17-20\% and 16-18\%, respectively (Tables 4, 5). The relative amounts of 18:0 were about 2\% in the four benthic abyssal species (Abyssocottus gibbosus, Abyssocottus korotneffi, Cottinella boulengeri and Batrachocottus nikolskii) the habitat of which reaches the depths of 1400-1600 m (Tables 4, 5). In the benthic eurybathic and benthopelagic species, the relative amounts were higher, with medians $4 \%$ and large variation (means 3-7\%) among the species (Tables 4, 5). The benthic abyssal Neocottus thermalis, living on hydrothermal field at the depth of only $400-480 \mathrm{~m}$, also contained $4 \%$ of 18:0 (Table $5)$.

The benthic abyssal fishes contained significantly larger proportions of monounsaturated FAs (MUFAs) than the benthic eurybathic and benthopelagic fishes (median $45 \%$ versus 23 and $14 \%$ in the eurybathic and benthopelagic fishes, respectively, $\mathrm{H}=31.0, \mathrm{P}$ $<0.001$ ) (Fig. 5a). The abyssal fishes contained 12\% median level of 16:1n-7 while the eurybathic and benthopelagic ones had only $4 \%$ (Table 4). In 18:1n-9, there was a decreasing trend of the medians: 24,13 and $6 \%$, from the abyssal via eurybathic to benthopelagic fishes (Table 4). When species means were compared, the variability in the levels of these two major MUFAs was the largest in the eurybathic fish group (Table 5).

The major MUFAs of the fishes, $16: 1 n-7$ and 18:1n-9 are products of $\Delta 9$ desaturase enzyme, inserting the first double bond into the $9^{\text {th }}$ carbon of 16:0 or 18:0, calculated from carboxyl group ( $n-x$ calculated from methyl end). Thus calculating the ratios 16:1n-7/16:0 and 18:1n-9/18:0 gives indices, which describe the activity of this desaturation, which may have happened in either the dietary organisms or in the tissues of the fish, or in both. For the benthic abyssal fishes, the median of the ratio 16:1n-7/16:0 was 0.9 (wt\% per wt $\%$ ) while in the benthic eurybathic and benthopelagic fishes it remained at $0.2(\mathrm{H}=24.3, \mathrm{P}<0.001)$ (Fig. 5b). The ratio 18:1n-9/18:0 was 13 in the abyssal fishes but only 3 and 2 in the eurybathic and benthopelagic species, respectively $(\mathrm{H}=33.7, \mathrm{P}<0.001)$ (Fig. $5 \mathrm{c})$.

The muscles of the benthic abyssal fishes contained significantly smaller proportions of polyunsaturated FAs (PUFAs) than the benthic eurybathic and benthopelagic fishes (median $32 \%$ versus $51 \%$ and $60 \%$ in the eurybathic and benthopelagic fishes, respectively, $\mathrm{H}$ $=28.5, \mathrm{P}<0.001)($ Fig. 6). This difference was largely due to the high proportions of 22:6n-3 in the eurybathic and benthopelagic fishes. In the abyssal fishes the median value of 22:6n-3 was only $7 \%$ while the eurybathic and benthopelagic fishes contained $19 \%$ in $33 \%$ (Table 4). The abyssal species contained also less 20:4n-6 and 20:5n-3 than the eurybathic fishes (Table 4). The eurybathic species means of 20:4n-6 were consistently higher that in the species from the other ecological groups (Table 5). 
in the muscle samples of the Cottoidei fishes. We tested this principle with our comparative data by studying the regression of the PUFA totals and MUFA/SFA ratios (this ratio is indicating whether 16:1n-7 and 18:1n-9 and other minor MUFAs had been produced from their SFA precursors). Statistically significant negative correlation $\left(\mathrm{R}^{2}=0.7996, \mathrm{P}<0.001\right.$, arcsine transformed data) was found (Fig. 7). The axis intersections of the fitted line ( $\mathrm{y}=-$ $0.0475 x+3.4367$, with no transformation) also gave suggestions for theoretical requirements for the PUFA and MUFA contents in the muscle total lipids of these fish. The graph suggested that if the muscle tissue contains approximately 70\% PUFAs (x-axis intersection), the remaining $30 \%$ can be comprised of SFAs with no need for MUFA production. In addition, in the theoretical total absence of PUFA, the proportion of MUFAs should be more than 3-fold the amount of SFAs (y-axis intersection 3.5), thus meaning that about $75 \%$ of MUFA and 25\% SFA would be an alternative acceptable FA composition for the muscle total lipids of these fish.

The benthic abyssal fishes not only contained significantly lower relative amounts of PUFAs than the benthic eurybathic or benthopelagic fishes but the PUFAs present in their tissues were structurally different. The abyssal fishes had low n-3PUFA/n-6PUFA (later n$3 / n-6$ ) ratios (median 2.3), and these values showed an increasing trend via eurybathic (2.8) to benthopelagic fishes (8.5), in which the n-3PUFAs clearly dominated (Fig. 8). The ratios of the abyssal, eyrybathic and benthopelagic fishes were all statistically significantly different $(\mathrm{H}$ $=34.4, \mathrm{P}<0.001$, in pair wise comparisons $\mathrm{P}<0.001$, except abyssal versus eurybathic $\mathrm{P}=$ $0.047)$.

\section{Discussion}

The multivariate analyses clearly indicated that the FA compositions in the muscle of the Cottoidei fishes were associated with their assumed habitat and ecology (characterized in Table 2). The abyssal fishes were rich in MUFAs, the eurybathic and benthopelagic fishes contained high proportions of PUFAs, and the benthopelagic fishes were separated from the eurybathic ones with their higher percentages of n-3 PUFAs. In addition, the membership probabilities calculated for the individual samples suggested that the ecological groupings were correct. Only two species out of the 13 studied ones were found to have strong characteristics of two groups. In them, one half of the individuals belonged to the assumed group and the other half to another group. For example the muscle FA profiles suggested that the species Asprocottus abyssalis is a transitional form between the benthic abyssal and 
benthic eurybathic groups (the two individuals of the species Batrachocottus nikolskii do not allow making firm conclusions). It is of note that the muscle FA composition of Cyphocottus species and Cottocomephorus grewinkii could have been affected by their late spring spawning (Table 2) presumably causing recent lipid catabolism and thus affecting muscle FA composition in summer (Henderson et al. 1984). However the FA compositions of these species were not exceptional in their ecological groups, which suggest that variation in reproductive stage did not impair data interpretation.

The SFAs have high melting points and thus their concentrations are usually low in the tissues of cold-water fish. In the Cottoidei fish of Lake Baikal the median percentages of SFAs were $21 \%$ in the abyssal fishes and $25-26 \%$ in the eurybathic and benthopelagic fishes, while temperate fish usually contain 35-42 \% SFAs and in tropical fish the value can exceed 50\% (Nair 1978; Tanakol et al. 1999). Inserting of the first double bond into a SFA dramatically decreases the melting point of the FA and the lipids they are incorporated in (Knothe and Dunn 2009). The responsible enzyme, $\Delta 9$ desaturase is ubiquitously expressed in fish and all eukaryotic organisms and found activated in cold acclimation and adaptation (Trueman et al. 2000 Castro et al. 2011). Thus a high proportion of MUFAs, such as found in the benthic abyssal fish of this study (median 45\%) meets the thermal requirements of the habitat.

The high ratios of 16:1n-7/16:0 and 18:1n-9/18:0 in the benthic abyssal fish can in large part be explained by the diet, i.e. temperature adaptation that has already occurred in the lipids of dietary organisms, and if required the remaining temperature adaptation of tissue lipid fluidity can be achieved by the $\Delta 9$ desaturation of SFAs in the tissues of the fish. The benthic sediments provide the fish with bacteria, diatom-rich mass of sunk algae and invertebrates, the lipids of which contain large percentages of both SFAs and MUFAs (Zink et al. 2008; Kelly and Scheibling 2012; Shishlyannikov et al. 2014). Deep-sea bacteria are known to exhibit large increases in MUFAs in response to elevated cultivation pressure (Allen et al. 1999), which suggest that the deepest living bacterial mat may also contain significant amounts of MUFAs. Baikal diatoms were reported to be rich in 16:1n-7, and their ratios of 16:1/16:0 are comparable or even higher than those found in the muscle of abyssal fish (Shishlyannikov et al. 2014). However, in the deep sea gammarids, mollusks and crustaceans the ratio $16: 1 / 16: 0$ is at highest about 0.5 and mostly much lower than in the abyssal fish muscle (Morris 1984, Kozlova and Khotimchenko 1993, Dembitsky 1994a,b). Instead of providing much 16:1n-7 (or any other 16:1 isomer), the deep sea gammarids and mollusks contain very high proportion of 18:1n-9, comparable to the levels of the abyssal fish muscle, and at least 3 times the levels found in the common crustaceans of Lake Baikal, 
Epishura baicalensis and Macrohectopus branickii (Morris 1984, Kozlova and Khotimchenko 1993, Dembitsky 1994a,b). Thus a combined diet of diatom rich debris and gammarids or other invertebrates could provide the abyssal fish with both high amounts of 16:1n-7 and 18:1n-9. Provided that the dietary supply of MUFA would not ensure proper tissue lipid fluidity, then fish have the capacity to convert SFAs to MUFAs by the $\Delta 9$-desaturase enzyme (Trueman et al. 2000). Thus, we hypothesized that if the tissue PUFA content is low and the MUFA/SFA ratio of the diet would not ensure proper membrane fluidity, the fish species entering the deepest layers of the water column and being (due to the combined effect of low temperature and high pressure) subject to the highest risk of solidifying cellular membranes, are able to adjust their tissue lipid fluidity by converting SFAs to MUFAs. Thus this ratio MUFA/SFA of their tissues would always be optimal.

Both PUFAs and MUFAs lower lipid melting point, and thus the proper fluidity of tissue lipids can be obtained by adjusting their contents of MUFAs according to the supply of dietary PUFAs. Apparently the main reasons for the MUFA dominance over PUFA in the muscle of the Cottoidei species inhabiting the deepest layers of Lake Baikal is the lack of PUFAs in the abyssal food web. There was a striking difference in the relative amounts of MUFAs and PUFAs in the benthic abyssal fish versus the benthic eurybathic and benthopelagic fishes (Fig. 5a, 6). In the abyssal fishes, MUFAs were present with $45 \%$ levels, and thus they dominated over PUFAs. The MUFA levels of the benthic eurybathic and benthopelagic fishes were one half or less of the abyssal values. Instead, the eurybathic and benthopelagic fishes had very high PUFA levels, about 50-60\%. The PUFA level of the abyssal fishes was only about $30 \%$. This suggests that the trophic links between the benthic abyssal fish species and the organisms of the productive photic layers rich in plankton-derived PUFAs are weak. Divergent muscle FA compositions have also been found among different deep ocean fishes (Bakes et al. 1995; Lea et al. 2002; Økland et al. 2005; Drazen et al. 2009; Penthybridge et al. 2010). The range reported in these previous studies for the total proportions of MUFAs and PUFAs have varied between $20 \%$ and $65 \%$. Even the relative amounts of SFAs were found to vary between $15 \%$ and $40 \%$. Thus different deep-sea fish appear to tolerate a very different tissue FA composition, and low water temperature or the high pressure as such do not necessitate replacing PUFAs by MUFAs. In addition to modifying FA structures, mechanical strength against pressure can be achieved by increasing tissue cholesterol levels (Kato and Hayashi 1999). In the different benthic fish of Lake Baikal, however, this variability in the relative MUFA and PUFA contents was related to the habitat depth, which suggest very different dietary supplies. 
With the ideal comparative data of Lake Baikal Cottoidei fishes, we studied the concept of PUFA levels regulating the MUFA levels in deep sea fish. It has been proposed that high dietary PUFA levels regulate gene transcription and inhibit the production of the $\Delta 9$ desaturase enzyme, which results in lowered rate of MUFA production from the SFA precursors (Ntambi 1999). This feedback system would integrate the contributions from the dietary PUFA supply and endogenous MUFA production to membrane fluidity and ensure accurate viscosity homeostasis. Naturally this compositional regulation may largely happen in the dietary items of the fish already, but the MUFA levels are likely further modulated in the tissues of the fish. The FAS of total lipids studied originate partly from structural polar lipids and partly from neutral storage lipids but both types of lipids need to be in the proper semiviscous physical state for optimal functions and to be accessible for energy production (Hazel 1995; Werbrouck et al. 2016). The statistically significant negative correlation found between the muscle PUFA percentage and the ratio MUFA/SFA (indicating the functioning of $\Delta 9$ desaturase) suggest that the supply of PUFAs determines the degree of MUFA production (Fig. 7). In addition this analysis suggested that if the muscle tissue contains $70 \%$ PUFAs, the remaining $30 \%$ can be comprised of SFAs, or alternatively about $75 \%$ MUFAs and $25 \%$ SFAs would at least in theory be equally acceptable FA composition for the muscle total lipids of the Cottoidei fish. However, the lowest PUFA level recorded (i.e. minimum requirement) was $24 \%$ (Fig. 7 ), which clearly points out that, despite potentially sufficient for membrane fluidity control (Hazel 1995), the MUFAs cannot qualify for all the biological functions that require the 22:6n-3, usually plentiful in fish, or other highly unsaturated FAs (Stillwell and Wassall 2003).

The n-3/n- 6 ratios were very high for the benthopelagic fishes and low in the benthic abyssal and eurybathic fishes. The ratios found in the abyssal and eurybathic fishes of Lake Baikal were similar to those reported for shallow-water freshwater fish consuming benthic prey (Ahlgren et al. 1994), and earlier we found very similar values for several fish species inhabiting shallow waters of lake Baikal and having benthic influence in their diets, i.e. the ide Leuciscus idus, roach Rutilus rutilus and silver carp Carassius auratus (1.4-2.3) (GrahlNielsen et al. 2011). In the same way, the $n-3 / n-6$ ratios of the benthopelagic species studied in this work resembled the ratios of previously studied Baikal fish species utilizing pelagic prey, such as whitefish Coregonus baikalensis and grayling Thymallus baikalensis (values close to 7) (Grahl-Nielsen et al. 2011). The rich supply of n-3 PUFAs from the primary producers of the photic water layer is a common global phenomenon in aquatic ecosystems (Brett and Müller-Navarra 1997), and also worldwide freshwater fish have in general smaller 
n-3/n-6 ratios than pelagic Ocean fish (Ackman 1967; Steffens and Wirth 2005; AbouelYazeed 2013).

To conclude, the muscles of the Cottoidei fishes of Lake Baikal showed a remarkable flexibility in terms of FA composition. The abyssal fishes inhabiting the deepest layers of the lake had clear MUFA dominance and the eurybathic and benthopelagic species had PUFA dominance. In addition, the values for n-3/n-6 ratio decreased with increasing water depth, which may reflect weak trophic links between the abyssal fish species and the primary producers of the photic water layer rich n-3PUFA. Ahlgren et al. (2009) have summarized data of temporal and tropical freshwater fishes from shallow waters and concluded that the PUFA content and pattern in herbivorous-omnivorous fish are mainly controlled by the supply and quality of food, whereas in carnivorous fish species the tissue PUFA pattern goes through more extensive structural modifications. Our data of deep water freshwater fish of Lake Baikal showed that the main determinant of their muscle fatty acid composition was habitat depth, possibly involving more restricted choices of dietary items in the benthic abyssal habitats of the lake than in the benthopelagic habitat supporting PUFA-rich dietary items. The fact that the divergent MUFA/SFA ratio inversely correlated with the divergent relative amount of PUFAs in the muscles of the Cottoidei fish suggests efficient viscosity control integrating the MUFA and PUFA contents in the tissue.

The current work encourages conducting further studies to understand the role of lipids and FAs in the biology of the Cottoidei fishes. Controlled feeding experiments with abyssal species are not feasible, but detailed mass spectrometric studies on the molecular structures of individual lipid species in each lipid class could further clarify the restrictions and possibilities for the incorporation of different FAs into the tissues of fish species living at extreme depths. Our work suggest that the true abyssal fishes of Lake Baikal required a $24 \%$ minimum level of PUFAs in their lipids. Thus, it is worth considering whether the expected environmental changes could cause such alterations in food web structure or accessibility of PUFA-rich food items for the fish that such minimum PUFA requirement would not be filled in the future. It is of note that the current study was conducted by sampling the fishes during summer, and therefore the potential seasonal changes in the foraging ecology, physiology and biochemistry of these deep living fishes remain to be studied further. 


\section{Acknowledgements}

Lake Baikal Protection Fund is gratefully acknowledged for organizing the international research expedition "Mirs on Lake Baikal" during 2008-2010. This study was supported by the Program of the Russian Academy of Sciences' Presidium (V.46.5.2; 2013-2016) and was funded by Russian Fundamental Research Fund (14-05-00516 A; 2014-2016). Assistance of Melissa Westberg in the statistical analyses is highly appreciated.

\section{References}

Abouel-Yazeed AM (2013) FAs Profile of Some Marine Water and Freshwater Fish. J Arabian Aquacult Soc 8:283-292

Ackman RG (1967) Characteristics of the fatty acid composition and biochemistry of some freshwater fish oils and lipids in comparison with marine oils and lipids. Comp Biochem Physiol 22:907-922

Ackman RG (1992) Application of gas-liquid chromatography to lipid separation and analysis: qualitative and quantitative analysis. In: Chow CK (ed) Fatty Acids in Foods and Their Health Implications. Marcel Dekker, New York, pp 47-63

Ahlgren G, Blomqvist P, Boberg M, Gustafsson IB (1994) Fatty acid content of the dorsal muscle - an indicator of fat quality in freshwater fish. J Fish Biol 45:131-157

Ahlgren G, Vrede T, Goedkoop W (2009) Fatty acid ratios in freshwater fish, zooplankton and zoobenthos - Are there specific optima? In: Arts MT, Brett MT, Kainz MJ (eds) Lipids in Aquatic Ecosystems. Springer, New York, pp 147-178

Allen EE, Facciotti D, Bartlett DH (1999) Monounsaturated but not polyunsaturated fatty acids are required for growth of the deep-sea bacterium Photobacterium profundum SS9 at high pressure and low temperature. Appl Environ Microbiol 65:1710-1720

Averina E, Grahl-Nielsen O, Bazarsadueva S, Radnaeva L (2011) Transformation through the food chain of lake Baikal hydrobionts fatty acids. Chem Nat Comp 46:857-861

Bakes MJ, Elliott NG, Greens GJ, Nichols PD (1995) Variation in lipid composition of some deep-sea fish (Teleostei: Oreosomatidae and Trachichthyidae). Comp Biochem Physiol B 111:633-642

Bazarsadueva SV, Radnaeva LD (2013) Fatty acid composition of deep water Baikal amphipods Ommatogammarus albinus. Chem Sustain Dev 21:533-537

Berg LS (1922). Fauna of Lake Baikal and its origin. Klimat i Zhizn, Moscow, pp 28-53 
Brett M, Müller-Navarra D (1997) The role of highly unsaturated fatty acids in aquatic foodweb processes. Freshwater Biol 38:483-499

Bühring SI, Christiansen B (2001) Lipids in selected abyssal benthopelagic animals: links to the epipelagic zone? Prog Oceanogr 50:369-382

Castro LFC, Wilson JM, Gonçalves O, Galante-Oliveira S, Rocha E, Cunha I (2011) The evolutionary history of the stearoyl-CoA desaturase gene family in vertebrates. BMC Evol Biol 11:132

Chandra S, Vander Zanden MJ, Heyvaert AC, Richards BC, Allen BC, Goldman CR (2005) The effects of cultural eutrophication on the coupling between pelagic primary production and benthic consumers. Limnol Oceanogr 50:1368-1376.

Cossins AR, Macdonald AG (1989) The adaptation of biological membranes to temperature and pressure: fish from the deep and cold. J Bioenerg Biomembr 21:115-135

Dembitsky VM, Kashin AG, Rezanka T (1994a) Comparative study of the endemic freshwater fauna of Lake Baikal V. Phospholipid and fatty acid composition of the deep-water amphipod crustacean Acanthogammarus (Brachyuropus) grewingkii. Comp Biochem Physiol 108B:443-448

Dembitsky VM, Rezanka T, Kashin AG (1994b) Comparative study of the endemic freshwater fauna of Lake Baikal IV. Phospholipid and fatty acid compositions of two gastropod molluscs of the genus Valvata. Comp Biochem Physiol 107B:325-330

Dembitsky VM, Rezanka T, Kashin AG (1994c) Comparative study of the endemic freshwater fauna of Lake Baikal. VI. Unusual fatty acid and lipid composition of the endemic sponge Lubomirskia baikalensis and its amphipod crustacean parasite Brandtia (Spinacanthus) parasitica. Comp Biochem Physiol 109B:415-426

Dorogostaisky VC (1923) To the taxonomy of Baikal basin' graylings. Proceedings of Irkutsk society of scientists, anthropologists and ethnographers, Irkutsk, pp 1-75

Drazen JC, Phleger CF, Guest MA, Nichols PD (2009) Lipid composition and diet inferences in abyssal macrourids of the eastern North Pacific. Mar Ecol Prog Ser 387:1-14

Grahl-Nielsen O, Averina E, Pronin N, Radnaeva L, Käkelä R (2011) Fatty acid profiles in different fish species in Lake Baikal. Aquat Biol 13:1-10

Hazel JR (1995) Thermal adaptation in biological membranes: is homeoviscous adaptation the explanation? Annu Rev Physiol 57:19-42

Henderson RJ, Sargent JR, Hopkins CCE (1984) Changes in the content and fatty acid composition of lipid in an isolated population of the capelin Mallotus villosus during sexual maturation and spawning. Mar Biol 78:255-263 
Hsieh S-L, Hu C-Y, Hsu Y-T, Hsieh T-J (2007) Influence of dietary lipids on the fatty acid composition and stearoyl-CoA desaturase expression in hybrid tilapia (Oreochromis niloticus $\times$ O. aureus) under cold shock. Comp Biochem Physiol B 147:438-444

Ju SJ, Kucklick JR, Kozlova T, Harvey HR (1997) Lipid accumulation and fatty acid composition during maturation of three pelagic fish species in Lake Baikal. J Gt Lakes Res 23:241-253

Kato M, Hayashi R (1999) Effects of high pressure on lipids and biomembranes for understanding high-pressure-induced biological phenomena. Biosci Biotechnol Biochem 63:1321-1328

Käkelä R, Käkelä A, Kahle S, Becker PH, Kelly A, Furness R (2005). Fatty acid signatures in plasma of captive herring gulls as indicators of demersal or pelagic fish diet. Mar Ecol Prog Ser 293:191-200

Käkelä R, Mattila M, Hermansson M, Haimi P, Uphoff A, Paajanen V, Somerharju P, Vornanen M (2008) Seasonal acclimatization of brain lipidome in a eurythermal fish (Carassius carassius) is mainly determined by temperature. Am J Physiol Regul Integr Comp Physiol 294:R1716-R1728

Kelly JR, Scheibling RE (2012) Fatty acids as dietary tracers in benthic food webs. Mar Ecol Prog Ser 446:1-22

Knothe G, Dunn RO (2009) A comprehensive evaluation of the melting points of fatty acids and esters determined by differential scanning calorimetry. J Am Oil Chem Soc $86: 843-856$

Kontula T, Kirilchik S, Väinolä R (2003) Endemic diversification of the monophyletic cottoid fish species flock in Lake Baikal explored with mtDNA sequencing. Mol Phylogenet Evol 27:143-155

Kozlova TA, Khotimchenko SV (1993) Fatty acid composition of endemic Baikal fish and crustacea. Comp Biochem Physiol B 105:97-103

Kozlova TA, Khotimchenko SV (2000) Lipids and fatty acids of two pelagic cottoid fishes (Comephorus sp.) endemic to Lake Baikal. Comp Biochem Physiol B 126:477-485

Lea M-A, Nichols PD, Wilson G (2002) Fatty acid composition of lipid-rich myctophids and mackerel icefish (Champsocephalus gunnari) - Southern Ocean food-web implications. Polar Biol 25:843-854

Macdonald AG (1984) The effect of pressure on the molecular structure and physiological functions of cell membranes. Philos Trans R Soc London Ser B 304:47-68 
Meier S, Mjøs SA, Joensen H, Grahl-Nielsen O (2006) Validation of a one-step extraction/methylation method for determination of fatty acids and cholesterol in marine tissues. J Chromatogr A 1104:291-298

Moore MV, Hampton SE, Izmest'eva LR, Silow EA, Peshkova EV, Pavlov BK (2009) Climate change and the world's "sacred sea" - Lake Baikal, Siberia. BioScience, 59:405-417.

Morris RJ (1984) The endemic faunae of Lake Baikal: their general biochemistry and detailed lipid composition. Proc R Soc Lond B 222:51-78

Nair PGV, Gopakumar K (1978) Fatty acid compositions of 15 species of fish from tropical waters. J Food Sci 43:1162-1164

Ntambi JM (1999) Regulation of stearoyl-CoA desaturase by polyunsaturated fatty acids and cholesterol. J Lipid Res 40:1549-1558

Økland HMW, Stoknes IS, Remme JF, Kjerstad M, Synnes M (2005) Proximate composition, fatty acid and lipid class composition of the muscle from deep-sea teleosts and elasmobranchs. Comp Biochem Physiol B 140:437-443

Pethybridge H, Daley R, Virtue P, Nichols P (2010) Lipid composition and partitioning of deepwater chondrichthyans: inferences of feeding ecology and distribution. Mar Biol $157: 1367-1384$

Sebert P (2002) Fish at high pressure: a hundred year history. Comp Biochem Physiol A $131: 575-585$

Semovski SV, Mogilev NY, Sherstyankin PP (2000) Lake Baikal ice: analysis of AVHRR imagery and simulation of under-ice phytoplankton bloom. J Mar Syst 27:117-130

Sideleva VG (1982) Seismosensoric system and ecology of Baikal Slimy sculpins. Nauka, Novosibirsk, pp 1-147 [In Russian]

Sideleva VG (1993) The endemic fish fauna of Lake Baikal, its origin and the conditions of existence. St. Petersburg State University, St. Petersburg, pp 1-40

Sideleva VG (2001) List of fishes from Lake Baikal with descriptions of new taxa of cottoid fishes. In: Pugachev ON, Balushkin AV (eds) New Contributions to Freshwater Fish Research. Proceedings of the Zoological Institute, vol. 287, St. Petersburg: Zoological Institute RAS, pp 45-79

Sideleva VG, Fialkov VA (2015) Cottoid fishes (Cottoidei) in deep-water hydrothermal vent community in Frolikha Bay, Lake Baikal (in Russian), Trudy VNIRO 156: 132-145

Shishlyannikov SM, Klimenkov IV, Bedoshvili YD, Mikhailov IS, Gorshkov AG (2014) Effect of mixotrophic growth on the ultrastructure and fatty acid composition of the diatom Synedra acus from Lake Baikal. J Biol Res (Thessalon) 21:15 
Somero GN (1992) Adaptations to high hydrostatic pressure. Annu Rev Physiol 54:557-577

636 Steffens W, Wirth M (2005) Freshwater fish - an important source of n-3 polyunsaturated fatty acids: review. Arch Pol Fish 13:5-16

Stillwell W, Wassall SR (2003) Docosahexaenoic acid: membrane properties of a unique fatty acid. Chem Phys Lipids 126:1-27

Taliev DN (1955) Slimy sculpins of Lake Baikal (in Russian). Publ. of Academy of Sciences of USSR, Moscow, pp 1-603

Tanakol R, Yazici Z, Sener E, Sencer E (1999) Fatty acid composition of 19 species of fish from the Black Sea and the Marmara Sea. Lipids 34:291-297

Trueman RJ, Tiku PE, Caddick MX, Cossins AR (2000) Thermal thresholds of lipid restructuring and $\Delta^{9}$-desaturase expression in the liver of carp (Cyprinus carpio 1.). $\mathbf{J}$ Exp Biol 203:641-650

Werbrouck E, Van Gansbeke D, Vanreusel A, De Troch M (2016) Temperature Affects the Use of Storage Fatty Acids as Energy Source in a Benthic Copepod (Platychelipus littoralis, Harpacticoida). PLoS ONE 11: e0151779

Wold S, Sjöström M (1977) SIMCA: a method for analyzing chemical data in terms of similarity and analogy. In: Kowalski B (ed) Chemometrics: Theory and Application. American Chemical Society, Washington, DC, pp 243-282

Zink K-G, Mangelsdorf K, Granina L, Horsfield B (2008) Estimation of bacterial biomass in subsurface sediments by quantifying intact membrane phospholipids. Anal Bioanal Chem 390:885-896 


\begin{tabular}{|c|c|c|c|c|c|}
\hline & Species & $\begin{array}{l}\text { Catch location } \\
\text { and time }\end{array}$ & $\begin{array}{l}\text { Catch } \\
\text { method* }\end{array}$ & $\begin{array}{l}\text { Catch } \\
\text { depth, m }\end{array}$ & Species ecology \\
\hline \multirow[t]{4}{*}{$\begin{array}{l}\text { Cottidae/ } \\
\text { Cottocomephorinae }\end{array}$} & $\begin{array}{l}\text { Batrachocottus } \\
\text { multiradiatus } \\
(\mathrm{N}=2)\end{array}$ & $\begin{array}{l}\text { Frolikha bay, } \\
\text { Aug } 2009\end{array}$ & $\mathrm{~m}$ & 409 & benthic, eurybathic \\
\hline & $\begin{array}{l}\text { Batrachocottus } \\
\text { nikolskii } \\
(\mathrm{N}=2)\end{array}$ & $\begin{array}{l}\text { Frolikha bay, } \\
\text { Aug } 2009\end{array}$ & $\mathrm{~m}$ & 424 & benthic, abyssal \\
\hline & $\begin{array}{l}\text { Cottocomephorus } \\
\text { grewingkii } \\
(\mathrm{N}=4)\end{array}$ & $\begin{array}{l}\text { Selenga river delta, } \\
\text { July } 2010\end{array}$ & $\mathrm{t}$ & 200 & benthopelagic \\
\hline & $\begin{array}{l}\text { Cottocomephorus } \\
\text { inermis } \\
(\mathrm{N}=8)\end{array}$ & $\begin{array}{l}\text { Northern Baikal, } \\
\text { July } 2010\end{array}$ & $\mathrm{t}$ & not known & benthopelagic \\
\hline \multirow[t]{9}{*}{ Abyssocottidae } & $\begin{array}{l}\text { Abyssocottus } \\
\text { gibbosus } \\
(\mathrm{N}=6)\end{array}$ & $\begin{array}{l}\text { Izhimei, } \\
\text { July } 2009\end{array}$ & $\mathrm{t}, \mathrm{m}$ & 1597 & benthic, abyssal \\
\hline & $\begin{array}{l}\text { Abyssocottus } \\
\text { korotneffi } \\
(\mathrm{N}=4)\end{array}$ & $\begin{array}{l}\text { mud volcano "Saint } \\
\text { Petersburg", July } \\
2009\end{array}$ & $\mathrm{t}, \mathrm{m}$ & 1396 & benthic, abyssal \\
\hline & $\begin{array}{l}\text { Asprocottus } \\
\text { abyssalis } \\
(\mathrm{N}=6)\end{array}$ & $\begin{array}{l}\text { Location not known, } \\
\text { July } 2010\end{array}$ & $\mathrm{t}$ & not known & benthic, eurybathic \\
\hline & $\begin{array}{l}\text { Cottinella } \\
\text { boulengeri } \\
(\mathrm{N}=2)\end{array}$ & $\begin{array}{l}\text { Northern Baikal, } \\
\text { July } 2010\end{array}$ & $\mathrm{t}$ & 690 & benthic, abyssal \\
\hline & $\begin{array}{l}\text { Cyphocottus } \\
\text { species } \\
(\mathrm{N}=8)\end{array}$ & $\begin{array}{l}\text { Northern Baikal, } \\
\text { July } 2010\end{array}$ & $\mathrm{t}$ & not known & benthic, eurybathic \\
\hline & $\begin{array}{l}\text { Limnocottus } \\
\text { bergianus } \\
(\mathrm{N}=2)\end{array}$ & $\begin{array}{l}\text { Frolikha bay, } \\
\text { Aug } 2009\end{array}$ & $\mathrm{~m}$ & 400 & benthic, eurybathic \\
\hline & $\begin{array}{l}\text { Limnocottus } \\
\text { griseus } \\
(\mathrm{N}=8)\end{array}$ & $\begin{array}{l}\text { Chivyrkuisky bay, } \\
\text { July } 2010\end{array}$ & $\mathrm{t}$ & 400 & benthic, eurybathic \\
\hline & $\begin{array}{l}\text { Limnocottus } \\
\text { pallidus } \\
(\mathrm{N}=8)\end{array}$ & $\begin{array}{l}\text { Chivyrkuisky bay, } \\
\text { July } 2010\end{array}$ & $\mathrm{t}$ & 400 & benthic, eurybathic \\
\hline & $\begin{array}{l}\text { Neocottus } \\
\text { thermalis } \\
(\mathrm{N}=2)\end{array}$ & $\begin{array}{l}\text { Frolikha bay, } \\
\text { Aug } 2009\end{array}$ & $\mathrm{~m}$ & 409 & benthic, abyssal \\
\hline
\end{tabular}

Table 1. Examined fish species of the Cottidae/Cottocomephorinae and Abyssocottidae families, information on their collection, and species ecology. 
Table 2. Habitat, diet and spawning time of the examined fish species of the Cottidae/Cottocomephorinae and Abyssocottidae families arranged by species ecology.

\begin{tabular}{|c|c|c|c|c|c|}
\hline Species ecology & Species & $\begin{array}{l}\text { Habitat } \\
\text { depth }(\mathrm{m})\end{array}$ & $\begin{array}{l}\text { Preferred } \\
\text { ground }\end{array}$ & Diet & Spawning time \\
\hline \multirow[t]{5}{*}{$\begin{array}{l}\text { benthic, } \\
\text { abyssal }\end{array}$} & $\begin{array}{l}\text { Abyssocottus } \\
\text { gibbosus }\end{array}$ & $400-1600$ & silty, silty-stony & bottom gammarids & Jan-Feb \\
\hline & $\begin{array}{l}\text { Abyssocottus } \\
\text { korotneffi }\end{array}$ & $200-1600$ & muddy & bottom gammarids & winter \\
\hline & $\begin{array}{l}\text { Cottinella } \\
\text { boulengeri }\end{array}$ & $400-1600$ & silty-calcarous & $\begin{array}{l}60 \% \text { phytoplankton debris, } \\
40 \% \text { gammarids and other } \\
\text { animals }\end{array}$ & $\begin{array}{l}\text { late autumn- } \\
\text { early winter }\end{array}$ \\
\hline & $\begin{array}{l}\text { Batrachocottus } \\
\text { nikolskii }\end{array}$ & $100-1400$ & silty-stony & golomyanka, also invertebrates & Apr-May \\
\hline & $\begin{array}{l}\text { Neocottus } \\
\text { thermalis }\end{array}$ & $400-480$ & $\begin{array}{l}\text { hydrothermal field; } \\
\text { silt, bacterial and } \\
\text { debris mat }\end{array}$ & amphipods in bacterial mat & no record \\
\hline \multirow[t]{6}{*}{$\begin{array}{l}\text { benthic, } \\
\text { eurybathic }\end{array}$} & $\begin{array}{l}\text { Asprocottus } \\
\text { abyssalis }\end{array}$ & $150-1400$ & muddy & small gammarids & Sept-Feb \\
\hline & $\begin{array}{l}\text { Limnocottus } \\
\text { griseus }\end{array}$ & $200-1300$ & silty-stony & mollusks and gammarids & $\begin{array}{l}\text { late autumn- } \\
\text { early winter }\end{array}$ \\
\hline & $\begin{array}{l}\text { Limnocottus } \\
\text { bergianus }\end{array}$ & $100-1000$ & muddy & $\begin{array}{l}\text { amphipods, including } \\
\text { Brachyuropus grewingkii }\end{array}$ & spring \\
\hline & $\begin{array}{l}\text { Limnocottus } \\
\text { pallidus }\end{array}$ & $100-1000$ & muddy, silty, sandy & $\begin{array}{l}90 \% \text { gammarids, } 5 \% \text { young } \\
\text { Cottoidei fish }\end{array}$ & Feb-Mar \\
\hline & $\begin{array}{l}\text { Batrachocottus } \\
\text { multiradiatus }\end{array}$ & $50-900$ & clay & amphipods & Mar-May \\
\hline & $\begin{array}{l}\text { Cyphocottus } \\
\text { species }\end{array}$ & $30-600$ & muddy-stony & $\begin{array}{l}\text { bottom gammarids, pelagic } \\
\text { amphipods, oligochaetes and fish }\end{array}$ & Mar-June \\
\hline \multirow[t]{2}{*}{ benthopelagic } & $\begin{array}{l}\text { Cottocomephorus } \\
\text { inermis }\end{array}$ & $20-1200$ & $\begin{array}{l}\text { silty, silty-sandy } \\
\text { (part of the day in } \\
\text { water column) }\end{array}$ & $\begin{array}{l}\text { planktonic animals; } \\
\text { Macrohectopus branickii, } \\
\text { Epishura baikalensis, young } \\
\text { Cottocomephorus }\end{array}$ & Feb \\
\hline & $\begin{array}{l}\text { Cottocomephorus } \\
\text { grewingkii }\end{array}$ & $0.5-400$ & $\begin{array}{l}\text { silty, sandy, sandy- } \\
\text { stony (part of the day } \\
\text { in water column) }\end{array}$ & $\begin{array}{l}75 \% \text { planktonic, especially } \\
\text { Epishura baicalensis, and } 25 \% \\
\text { benthic animals }\end{array}$ & $\begin{array}{l}\text { Jan-Mar, May- } \\
\text { June }\end{array}$ \\
\hline
\end{tabular}

Information from Taliev 1955; Sideleva and Fialkov (2015) 


\begin{tabular}{|c|c|c|}
\hline & Metabolism in fish & Potential dietary source \\
\hline 14:0 & Main product of de novo synthesis 16:0 can be chain shortened to $14: 0$ & $\begin{array}{l}\text { Proteobacteria, diatoms (Kelly and Scheibling 2012); abundant in Baikal sediment } \\
\text { bacteria (Zink et al. 2008) and diatoms (Shishlyannikov et al 2014). }\end{array}$ \\
\hline 16:0 & Main product of fatty acid de novo synthesis & Ubiquitously in prokaryotes and eukaryotes \\
\hline $16: 1 n-9$ & $\begin{array}{l}\text { De novo synthesized } 16: 0 \text { can be elongated to } 18: 0 \text {, and then desaturated to } 18: 1 \mathrm{n}-9 \text { and } \\
\text { subsequently chain shortened to } 16: 1 \mathrm{n}-9 \text { (the latter step is increasing lipid fluidity) }\end{array}$ & $\begin{array}{l}\text { Moderate levels in Baikal deep-sea mollusks and gammarids (Dembitsky et al. } \\
\text { 1994a,b) }\end{array}$ \\
\hline $16: 1 n-7$ & De novo synthesized $16: 0$ can be desaturated to $16: 1 \mathrm{n}-7$, which increases lipid fluidity & $\begin{array}{l}\text { Diatoms, bacteria (Kelly and Scheibling 2012); abundant in Baikal diatoms } \\
\text { (Shishlyannikov et al 2014) and sediment bacteria (Zink et al. 2008), and moderate } \\
\text { levels in the deep-sea gammarids (Morris 1984). }\end{array}$ \\
\hline 18:0 & De novo synthesized $16: 0$ can be elongated to $18: 0$, which decreases lipid fluidity & Various animal sources \\
\hline $18: 1 n-9$ & De novo synthesized $16: 0$ is elongated to $18: 0$, which is desaturated to $18: 1 \mathrm{n}-9$ & $\begin{array}{l}\text { Various sources; brown macroalgae, deep sea crustaceans and fishes (Kelly and } \\
\text { Scheibling 2012); abundant in Baikal golomyanka Comephorus baicalensis and } \\
\text { deep-sea gammarids (Morris 1984) }\end{array}$ \\
\hline $18: 1 n-7$ & De novo synthesized $16: 0$ is desaturated to $16: 1 \mathrm{n}-7$, which is elongated to $18: 1 \mathrm{n}-7$ & $\begin{array}{l}\text { Bacterial marker, which is also found in most animals but with a ratio } 18: 1 \mathrm{n}-7 / 18: 1 \mathrm{n}- \\
9<1 \text { (Kelly and Scheibling 2012); abundant in Baikal deep-sea gammarid, } \\
\text { Brachyuropus grewingkii (Dembitsky et al. 1994a). }\end{array}$ \\
\hline $18: 2 n-6$ & Fish do not de novo synthesize & $\begin{array}{l}\text { Vascular plants, green macroalgae (Kelly and Scheibling 2012); moderate levels in } \\
\text { Baikal deep-sea mollusks and gammarids (Dembitsky et al. 1994a,b). }\end{array}$ \\
\hline $20: 4 n-6$ & Fish do not de novo synthesize but can convert dietary $18: 2 n-6$ to $20: 4 n-6$ & $\begin{array}{l}\text { Protozoa, microeukaryotes, red algae (Kelly and Scheibling 2012); based on fish } \\
\text { studies of Lake Baikal and North Atlantic, elevated level of 20:4n-6 and other C20- } \\
22 \text { n-6 PUFAs was linked to benthic ecology (Grahl-Nielsen et al 2011, Käkelä et al } \\
\text { 2005). }\end{array}$ \\
\hline $20: 5 n-3$ & Fish do not de novo synthesize but can convert dietary n-3 precursors to $20: 5 n-3$ & $\begin{array}{l}\text { Diatoms, brown and red macroalgae (Kelly and Scheibling 2012); abundant in Baikal } \\
\text { diatoms (Shishlyannikov et al 2014), and crustacea Epishura baicalensis and } \\
\text { Macrohectopus branickii (Kozlova and Khotimchenko 1993) but low in the deep-sea } \\
\text { gammarids and mollusks (Dembitsky et al. 1994a,b) }\end{array}$ \\
\hline $22: 5 n-6$ & Fish do not de novo synthesize but can convert $18: 2 \mathrm{n}-6$ or $20: 4 \mathrm{n}-6$ to $22: 5 \mathrm{n}-6$ & No specific abundant source but can be produced in fish from the other $n-6$ PUFAs \\
\hline $22: 5 n-3$ & Fish do not de novo synthesize but can elongate $20: 5 n-3$ to $22: 5 n-3$ & No specific abundant source but can be produced in fish from the other n-3 PUFAs \\
\hline $22: 6 n-3$ & Fish do not de novo synthesize but can convert $20: 5 n-3$ or $22: 5 n-3$ to $22: 6 n-3$ & $\begin{array}{l}\text { Dinoflagellates, pelagic zooplankton, pelagic fish (Kelly and Scheibling 2012); } \\
\text { abundant in Baikal crustacea Epishura baicalensis and Macrohectopus branickii } \\
\text { (Kozlova and Khotimchenko 1993) but low in the diatoms (Shishlyannikov et al } \\
\text { 2014) and deep-sea gammarids and mollusks (Dembitsky et al. 1994a,b) }\end{array}$ \\
\hline
\end{tabular}




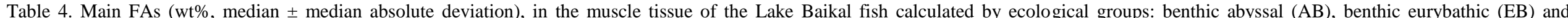

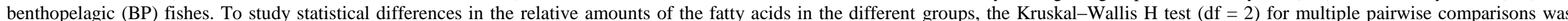
performed with the significance adjusted by the Bonferroni correction.

\begin{tabular}{|c|c|c|c|c|c|c|c|c|}
\hline & $\begin{array}{l}\text { benthic abyssal } \\
(\mathrm{N}=16)\end{array}$ & $\begin{array}{l}\text { benthic eurybathic } \\
(\mathrm{N}=34)\end{array}$ & $\begin{array}{l}\text { benthopelagic } \\
(\mathrm{N}=12)\end{array}$ & $\mathrm{H}$ & $\mathrm{P}$ & $\mathrm{AB}$ vs $\mathrm{EB}$ & $\mathrm{AB}$ vs $\mathrm{BP}$ & EB vs BP \\
\hline 14:0 & $4.1 \pm 1.2$ & $1.4 \pm 0.7$ & $2.0 \pm 0.9$ & 13.3 & $P=0.01$ & $\mathrm{P}=0.001$ & NS & NS \\
\hline $16: 0$ & $14.3 \pm 1.6$ & $17.7 \pm 1.4$ & $18.4 \pm 1.6$ & 23.2 & $P<0.001$ & $\mathrm{P}<0.001$ & $P<0.001$ & NS \\
\hline $16: 1 n-9$ & $0.4 \pm 0.3$ & $0.1 \pm 0.1$ & $0.02 \pm 0.02$ & 6.8 & $P=0.033$ & NS & $P=0.027$ & NS \\
\hline $16: 1 n-7$ & $11.6 \pm 1.3$ & $4.1 \pm 2.2$ & $3.9 \pm 2.2$ & 19.7 & $\mathrm{P}<0.001$ & $\mathrm{P}=0.001$ & $\mathrm{P}<0.001$ & NS \\
\hline 18:0 & $2.0 \pm 0.7$ & $4.1 \pm 0.7$ & $3.7 \pm 0.4$ & 17.2 & $\mathrm{P}<0.001$ & $\mathrm{P}<0.001$ & NS & NS \\
\hline $18: 1 n-9$ & $24.4 \pm 4.6$ & $13.3 \pm 3.8$ & $6.3 \pm 2.6$ & 41.5 & $\mathrm{P}<0.001$ & $\mathrm{P}<0.001$ & $\mathrm{P}<0.001$ & $\mathrm{P}=0.001$ \\
\hline $18: 1 n-7$ & $4.0 \pm 0.8$ & $3.4 \pm 0.8$ & $4.2 \pm 1.1$ & 4.4 & NS & - & - & - \\
\hline $18: 2 n-6$ & $4.2 \pm 1.4$ & $1.7 \pm 0.6$ & $1.0 \pm 0.2$ & 16.0 & $P<0.001$ & $P=0.024$ & $\mathrm{P}<0.001$ & NS \\
\hline $20: 4 n-6$ & $4.4 \pm 0.9$ & $7.9 \pm 2.1$ & $3.6 \pm 0.8$ & 35.7 & $\mathrm{P}<0.001$ & $\mathrm{P}<0.001$ & NS & $\mathrm{P}<0.001$ \\
\hline $20: 5 n-3$ & $9.7 \pm 1.1$ & $14.3 \pm 2.3$ & $12.2 \pm 1.3$ & 16.0 & $\mathrm{P}<0.001$ & $\mathrm{P}<0.001$ & NS & NS \\
\hline $22: 5 n-6$ & $1.0 \pm 0.3$ & $1.3 \pm 0.8$ & $0.6 \pm 0.4$ & 9.4 & $P=0.009$ & NS & NS & $P=0.007$ \\
\hline $22: 5 n-3$ & $1.3 \pm 0.7$ & $2.1 \pm 0.6$ & $2.4 \pm 0.5$ & 7.7 & $P=0.022$ & NS & $P=0.017$ & NS \\
\hline $22: 6 n-3$ & $6.6 \pm 1.8$ & $18.9 \pm 6.0$ & $32.7 \pm 4.3$ & 40.9 & $P<0.001$ & $\mathrm{P}<0.001$ & $\mathrm{P}<0.001$ & $P=0.002$ \\
\hline
\end{tabular}

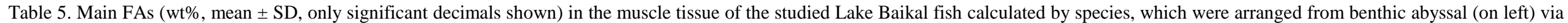
benthic eurybathic to benthopelagic species (on right)

\begin{tabular}{|c|c|c|c|c|c|c|c|c|c|c|c|c|c|}
\hline $\begin{array}{l}\text { Species } \\
\text { (sample } \\
\text { number) }\end{array}$ & $\begin{array}{l}\text { Abyssocottus } \\
\text { gibbosus } \\
(\mathrm{N}=6)\end{array}$ & $\begin{array}{l}\text { Abyssocottus } \\
\text { korotneffi } \\
(\mathrm{N}=4)\end{array}$ & $\begin{array}{l}\begin{array}{l}\text { Cottinella } \\
\text { boulengeri } \\
(\mathrm{N}=2)\end{array} \\
\end{array}$ & $\begin{array}{l}\begin{array}{l}\text { Batrachocottus } \\
\text { nikolskii } \\
(\mathrm{N}=2)\end{array} \\
\end{array}$ & $\begin{array}{l}\begin{array}{l}\text { Neocottus } \\
\text { thermalis } \\
(\mathrm{N}=2)\end{array} \\
\end{array}$ & 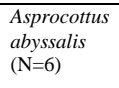 & $\begin{array}{l}\text { Limnocottus } \\
\text { griseus } \\
(\mathrm{N}=8)\end{array}$ & $\begin{array}{l}\text { Limnocottus } \\
\text { bergianus } \\
(\mathrm{N}=2)\end{array}$ & $\begin{array}{l}\text { Limnocottus } \\
\text { pallidus } \\
(\mathrm{N}=8)\end{array}$ & $\begin{array}{l}\text { Batrachocottus } \\
\text { multiradiatus } \\
(\mathrm{N}=2)\end{array}$ & $\begin{array}{l}\text { Cyphocottus } \\
\text { species } \\
(\mathrm{N}=8)\end{array}$ & $\begin{array}{l}\text { Cottocomephorus } \\
\text { inermis } \\
(\mathrm{N}=8)\end{array}$ & $\begin{array}{l}\text { Cottocomephorus } \\
\text { grewingkii } \\
(\mathrm{N}=4)\end{array}$ \\
\hline 14:0 & $4 \pm 1$ & $3 \pm 2$ & 4.5 & 4.0 & 0.9 & $1 \pm 1$ & $1.6 \pm 0.7$ & 0.8 & $2 \pm 1$ & 2.3 & $0.9 \pm 0.3$ & $1.5 \pm 0.9$ & $3 \pm 1$ \\
\hline 16:0 & $14 \pm 2$ & $14 \pm 1$ & 12.9 & 12.2 & 14.0 & $17 \pm 1$ & $17 \pm 2$ & 20.3 & $18 \pm 2$ & 18 & $17 \pm 2$ & $18 \pm 1$ & $16 \pm 2$ \\
\hline 16:1n-9 & $0.13 \pm 0.02$ & $3 \pm 2$ & 0.3 & 0.5 & 6.7 & $4 \pm 2$ & $0.9 \pm 0.4$ & 0.4 & $0.2 \pm 0.2$ & 1.4 & $0.04 \pm 0.02$ & $0.09 \pm 0.02$ & $0 \pm 0$ \\
\hline $16: 1 n-7$ & $9 \pm 3$ & $11 \pm 1$ & 12.0 & 15 & 15.3 & $11 \pm 6$ & $5 \pm 2$ & 1.7 & $4 \pm 2$ & 6.3 & $1.8 \pm 0.9$ & $5 \pm 4$ & $4 \pm 1$ \\
\hline 18:0 & $2 \pm 1$ & $2 \pm 1$ & 1.9 & 1.6 & 3.9 & $4 \pm 1$ & $3.3 \pm 0.5$ & 7.3 & $3.4 \pm 0.9$ & 4.2 & $5.5 \pm 0.9$ & $3.8 \pm 0.8$ & $3.4 \pm 0.8$ \\
\hline $18: 1 \mathrm{n}-9$ & $26 \pm 5$ & $24.3 \pm 0.7$ & 31.8 & 22.5 & 15.5 & $17 \pm 3$ & $13 \pm 3$ & 11.1 & $16 \pm 3$ & 14.6 & $9 \pm 1$ & $8 \pm 1$ & $3.1 \pm 0.9$ \\
\hline $18: 1 \mathrm{n}-7$ & $3.7 \pm 0.6$ & $2.7 \pm 0.4$ & 5.2 & 6.7 & 4.8 & $3.7 \pm 0.7$ & $3 \pm 1$ & 3.1 & $3 \pm 1$ & 3.3 & $2 \pm 1$ & $4 \pm 1$ & $2.7 \pm 0.7$ \\
\hline $18: 2 n-6$ & $4 \pm 1$ & $2 \pm 2$ & 5.0 & 4.2 & 1.5 & $1.7 \pm 0.7$ & $2.0 \pm 0.7$ & 0.8 & $2 \pm 1$ & 2.6 & $1.1 \pm 0.2$ & $1.0 \pm 0.2$ & $1.5 \pm 0.6$ \\
\hline $20: 4 n-6$ & $5 \pm 2$ & $4 \pm 1$ & 3.3 & 3.0 & 4.8 & $8 \pm 3$ & $8 \pm 1$ & 11.0 & $7 \pm 3$ & 7.7 & $10 \pm 1$ & $4 \pm 1$ & $3.2 \pm 0.7$ \\
\hline $20: 5 n-3$ & $11 \pm 2$ & $10 \pm 1$ & 8.2 & 6 & 9.4 & $10 \pm 3$ & $20 \pm 5$ & 9.6 & $14 \pm 2$ & 12.7 & $14 \pm 2$ & $11.2 \pm 0.8$ & $15 \pm 2$ \\
\hline $22: 5 n-3$ & $1.2 \pm 0.7$ & $3 \pm 2$ & 0.3 & 1.9 & 0.6 & $1.7 \pm 0.7$ & $1 \pm 1$ & 1.5 & $2.1 \pm 0.6$ & 2.5 & $2 \pm 1$ & $2.3 \pm 0.8$ & $8 \pm 6$ \\
\hline $22: 5 n-6$ & $0.9 \pm 0.4$ & $0.8 \pm 0.2$ & 0.4 & 0.8 & 1.4 & $1.0 \pm 0.9$ & $1 \pm 1$ & 0.9 & $1.1 \pm 0.8$ & 1.7 & $1 \pm 1$ & $0.5 \pm 0.3$ & $0.2 \pm 0.1$ \\
\hline $22: 6 n-3$ & $9 \pm 4$ & $8 \pm 2$ & 4.7 & 6 & 6.1 & $13 \pm 5$ & $14 \pm 4$ & 23.4 & $19 \pm 4$ & 17.7 & $27 \pm 4$ & $33 \pm 7$ & $31 \pm 3$ \\
\hline
\end{tabular}


Fig. 1. Taxonomic relationships of Lake Baikal Cottoidei fish species according to V.G. Sideleva (Sideleva, 1982; 2001). The classification according to D.N. Taliev is on the right side of the graph (Taliev, 1955). The chart was redrawn from Kontula et al. (2003) and the species studied here for FA composition are marked with bold text.

Fig. 2. A,B) Abyssal fishes from the genus Batrachocottus on the bottom of Lake Baikal, C) Batrachocottus nikolskii male is guarding clutch of eggs, D) Caught Limnocottus griseus. Photos by Selmeg Bazarsadueva (A, B, D) and Oleg Khlystov (C).

Fig. 3. A) PCA bilot plot (of scores and loadings) describing the compositional similarities and differences between the ecological groups of the studied Cottoidei fishes. Results of the pair wise SIMCA analyses testing the statistical significance (at $\mathrm{P}<0.05$ level) of the separations by PCA are shown as a table insert. The samples of benthic abyssal species were circled with black outline, samples of benthic eurybathic species with light grey outline, and those of benthopelagic species with dark grey outline. B) Membership plot indicating the probability $(0-1)$ each sample belonged to the PCA-based models of the three ecological groups. Species abbreviations: Ag, Abyssocottus gibbosus; Ak, Abyssocottus korotneffi; Cb, Cottinella boulengeri; Bn, Batrachocottus nikolskii; Nt, Neocottus thermalis; Aa, Asprocottus abyssalis; Lg, Limnocottus griseus; Lb, Limnocottus bergianus; Lp, Limnocottus pallidus; Bm, Batrachocottus multiradiatus; C, Cyphocottus species; Ci, Cottocomephorus inermis; Cg, Cottocomephorus grewingkii.

Fig. 4. Differences in the total proportions of saturated FAs (SFA, $H=21.6, P<0.001)$ in the muscle tissue of the benthic abyssal, benthic eurybathic and benthopelagic fishes indicated by boxplots showing (from top), the maximum value, third quartile, median, first quartile and minimum value (after the procedure removed a single outlier if detected). The values of ecological groups marked with different letter (the group with largest median receiving "a") differed according to the Kruskal-Wallis $\mathrm{H}$ test $(\mathrm{df}=2)$ of multiple comparisons using arcsine transformed data and significance levels adjusted by the Bonferroni correction (all significances marked by the different letters were $\mathrm{P}<0.001)$. Similar plots for the individual species are shown on right with no statistics (due to the low sample number in many species). Species abbreviations as in Fig 3. 
Fig. 5. Differences in the total proportions of monounsaturated FAs (MUFA, $\mathrm{H}=31.0, \mathrm{P}<$ $0.001)$, and ratios of $\mathrm{B}) 16: 1 \mathrm{n}-7 / 16: 0(\mathrm{H}=24.3, \mathrm{P}<0.001)$, and $\mathrm{C}) 18: 1 \mathrm{n}-9 / 18: 0(\mathrm{H}=33.7, \mathrm{P}<$ 0.001) in the muscle tissue of the benthic abyssal, benthic eurybathic and benthopelagic fish indicated by boxplots showing (from top), the maximum value, third quartile, median, first quartile and minimum value (after the procedure removed a single outlier if detected). The values of ecological groups with different letter (the group with largest median receiving "a") differed according to the Kruskal-Wallis $\mathrm{H}$ test $(\mathrm{df}=2)$ of multiple comparisons using arcsine transformed data and significance levels adjusted by the Bonferroni correction (all significances marked by the different letters were $\mathrm{P}<0.001$, except for $18: 1 \mathrm{n}-9 / 18: 0$, benthic eurybathic versus benthopelagic, $\mathrm{P}<0.032$ ). Similar plots for the individual species are shown on right with no statistics (due to the low sample number in many species). Species abbreviations as in Fig 3.

Fig. 6. Differences in the total proportions of polyunsaturated FAs (PUFA, $\mathrm{H}=28.5, \mathrm{P}<0.001$ ) in the muscle tissue of the benthic abyssal, benthic eurybathic and benthopelagic fish indicated by boxplots showing (from top), the maximum value, third quartile, median, first quartile and minimum value (after the procedure removed a single outlier if detected). The values of ecological groups with different letter (the group with largest median receiving "a") differed according to the Kruskal-Wallis $\mathrm{H}$ test $(\mathrm{df}=2)$ of multiple comparisons using arcsine transformed data and significance levels adjusted by the Bonferroni correction (all significances marked by the different letters were $\mathrm{P}<0.001)$. Similar plots for the individual species are shown on right with no statistics (due to the low sample number in many species). Species abbreviations as in Fig 3.

Fig. 7. Regression analysis of the interdependence between the muscle polyunsaturated FA (PUFA) totals and the MUFA/SFA ratio (integrating dietary supply of MUFAs and SFAs and potential conversion of SFA to MUFA in the fish) among the individual muscle samples showing a statistically significant negative correlation $\left(\mathrm{R}^{2}=0.80, \mathrm{P}<0.001 \mathrm{using}\right.$ arcsine transformed data; $\mathrm{y}=-0.0475 \mathrm{X}+3.4367$ with untransformed data to allow easy interpretation; see Results). The data points for the individuals of benthic abyssal fish species are marked with black diamonds, the points of benthic eurybathic fishes with light grey diamonds and the points of benthopelagic fishes with dark grey diamonds. 
Fig. 8. Differences in the ratio of n-3 PUFA total to n-6 PUFA total (n-3/n-6, H $=34.4, \mathrm{P}<$ 0.001 ) in the muscle tissue of the benthic abyssal, benthic eurybathic and benthopelagic fish indicated by boxplots showing (from top), the maximum value, third quartile, median, first quartile and minimum value (after the procedure removed a single outlier if detected). The values of ecological groups with different letter (the group with largest median receiving "a") differed according to the Kruskal-Wallis $\mathrm{H}$ test $(\mathrm{df}=2)$ of multiple comparisons using arcsine transformed data and significance levels adjusted by the Bonferroni correction (all significances marked by the different letters were $\mathrm{P}<0.001$, except for benthic abyssal versus benthic eurybathic, $\mathrm{P}<0.047)$. Similar plots for the individual species are shown on right with no statistics (due to the low sample number in many species). Species abbreviations as in Fig 3. 

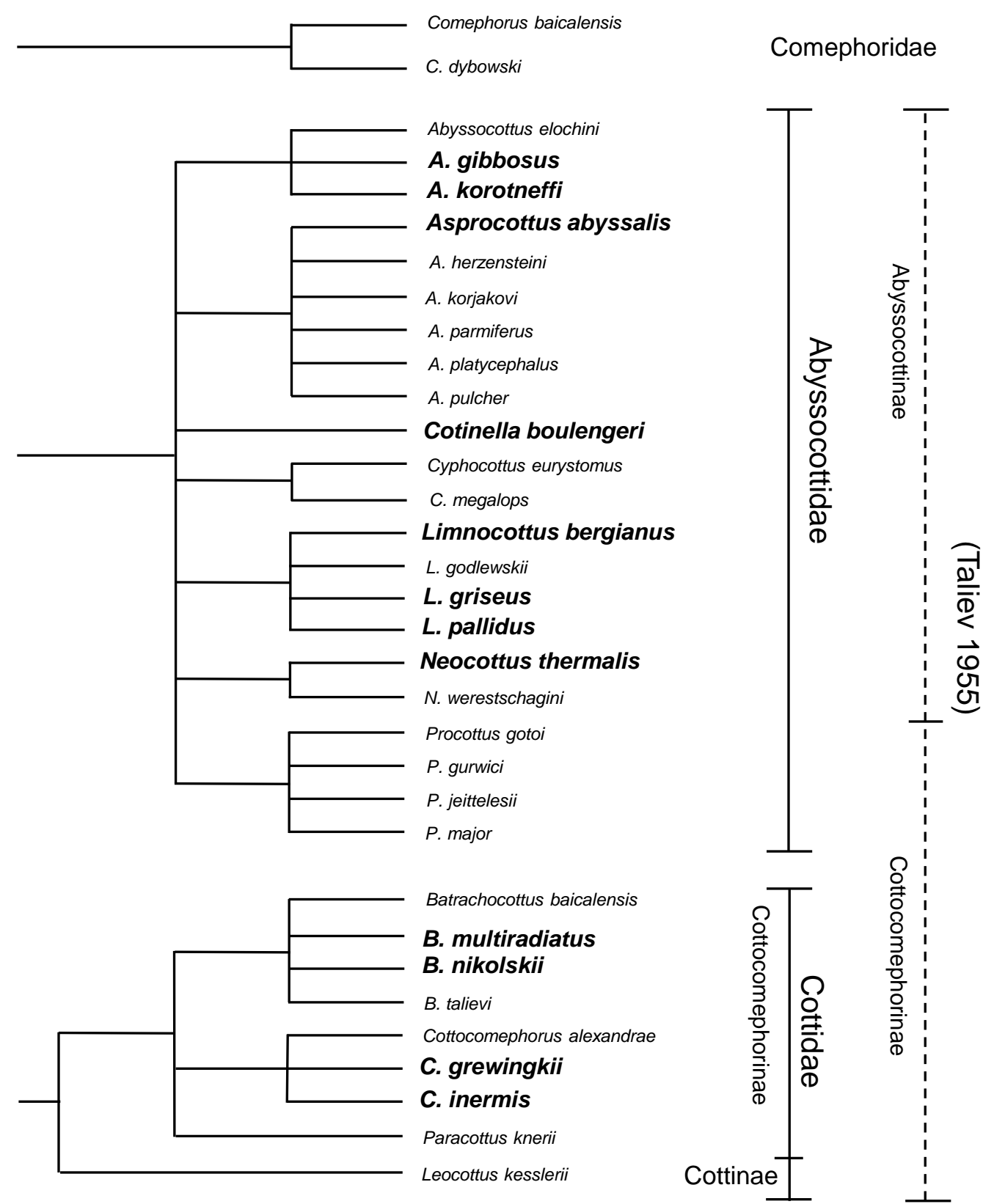

Fig. 1

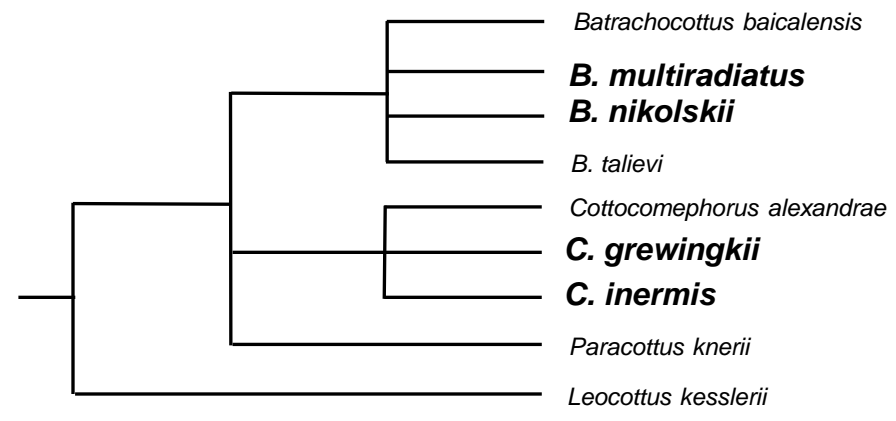

B. multiradiatus

B. talievi

Cottocomephorus alexandrae

C. grewingki

Paracottus knerii

Leocottus kessleri 
Radnaeva et al.

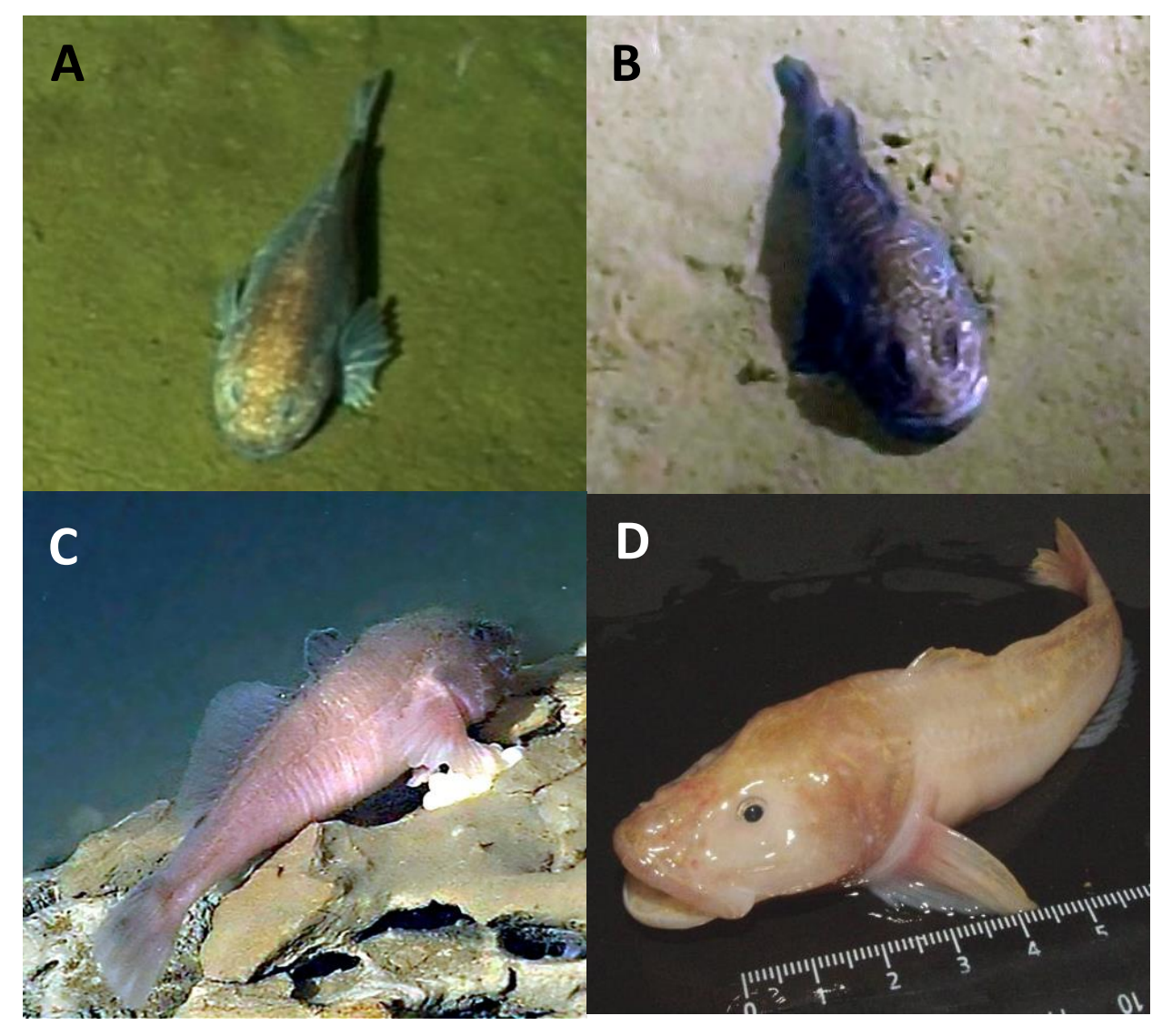

Fig. 2 


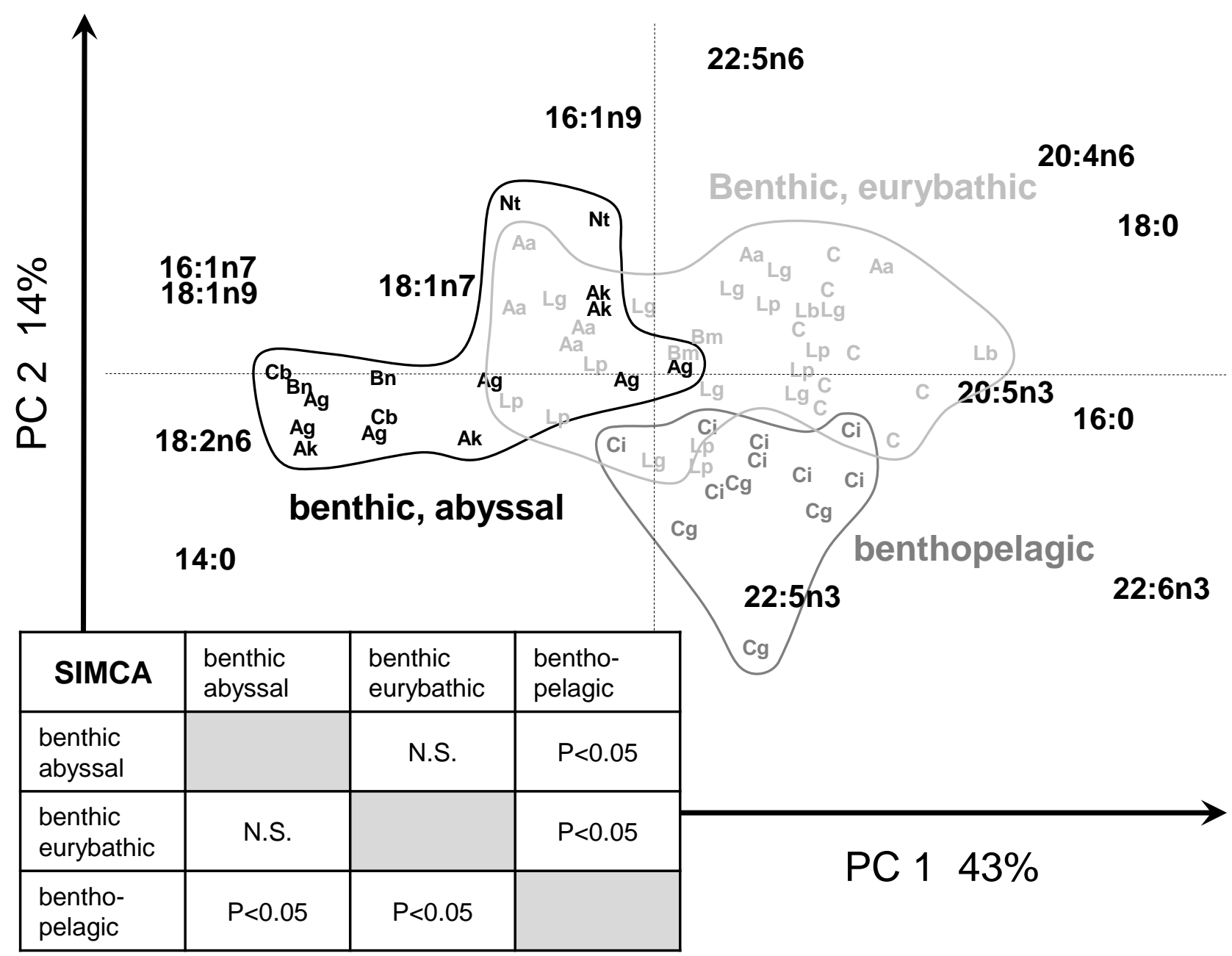

Fig. 3A 


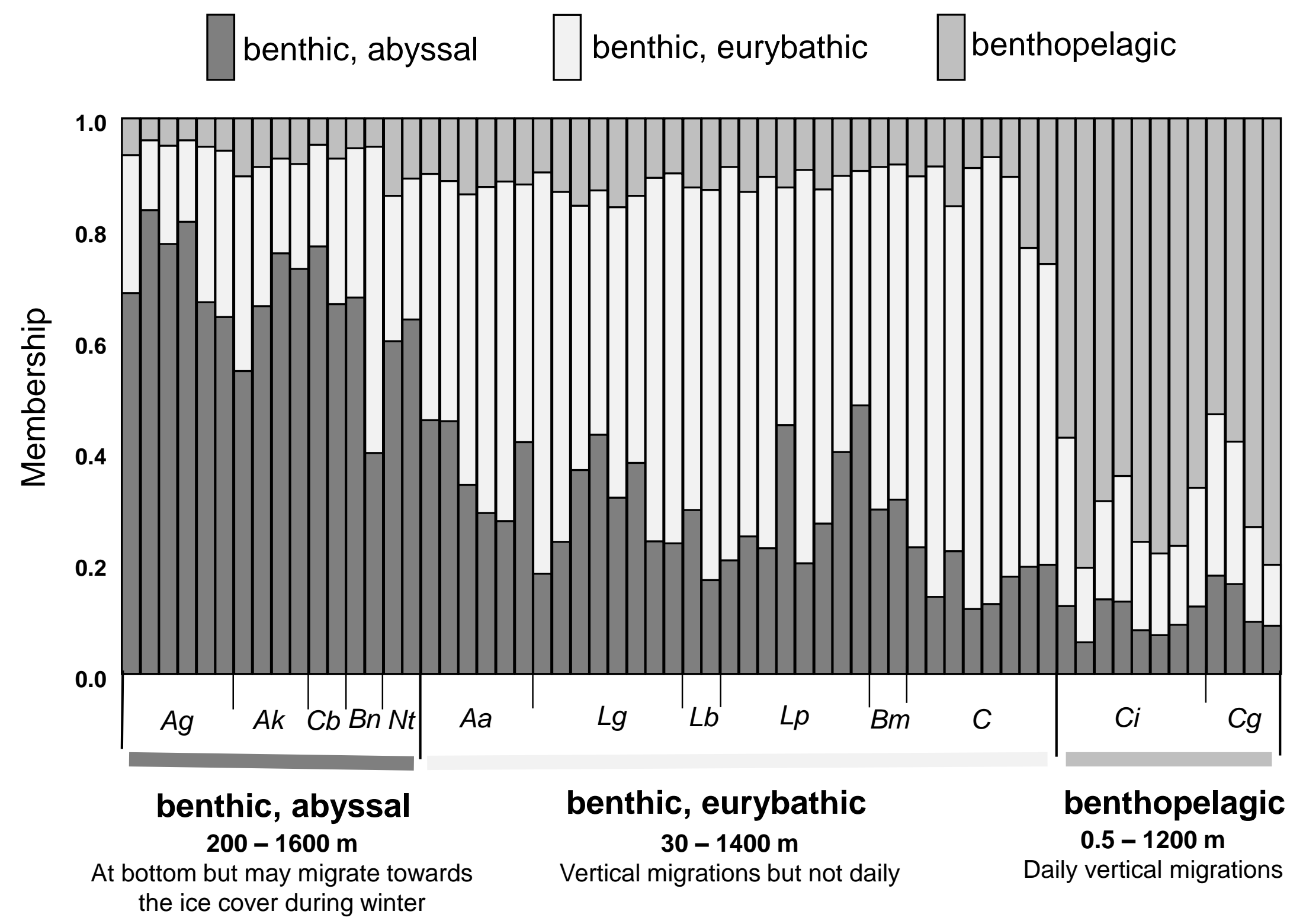

Fig. 3B 
Radnaeva et al.

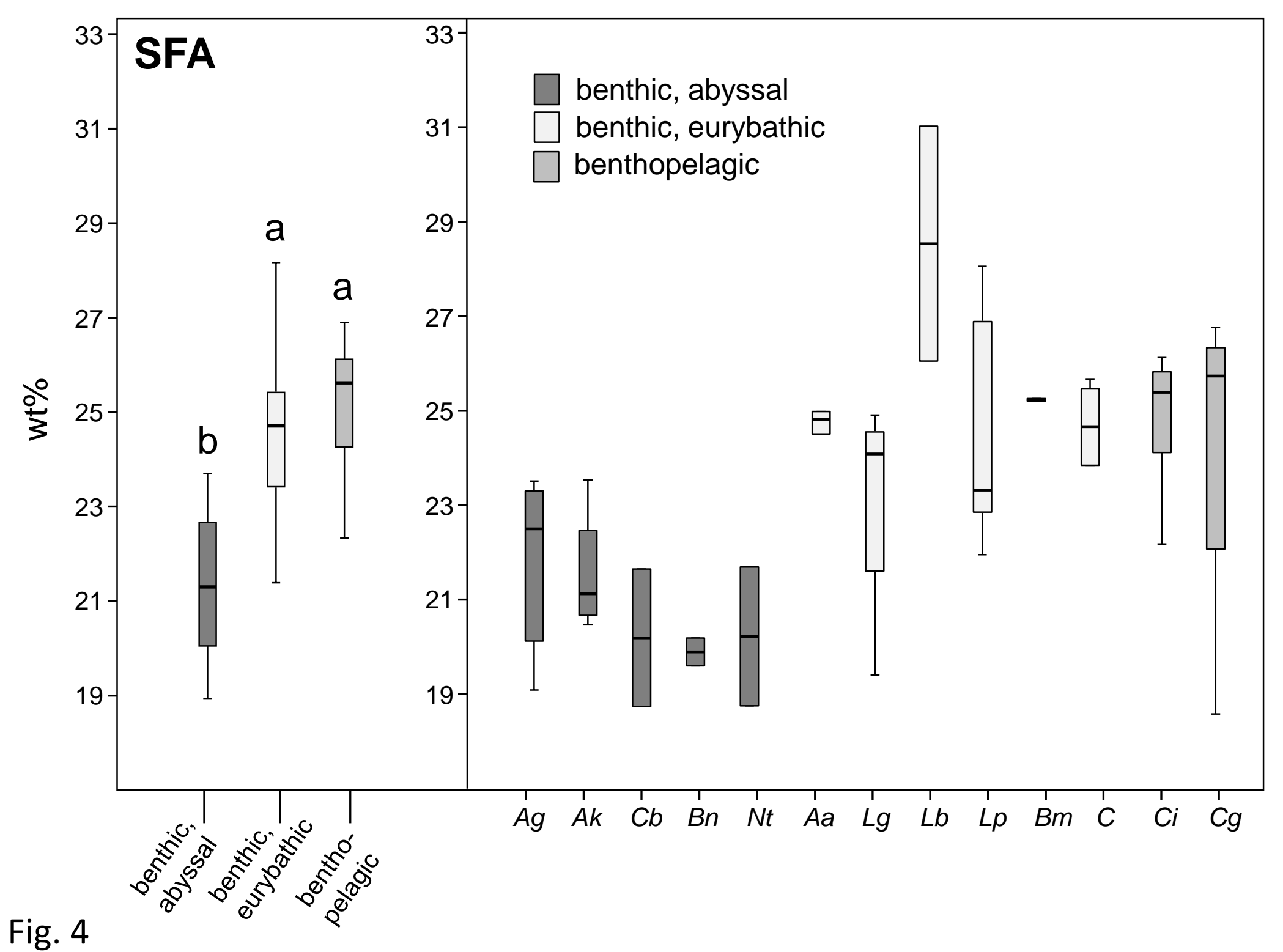


Radnaeva et al.

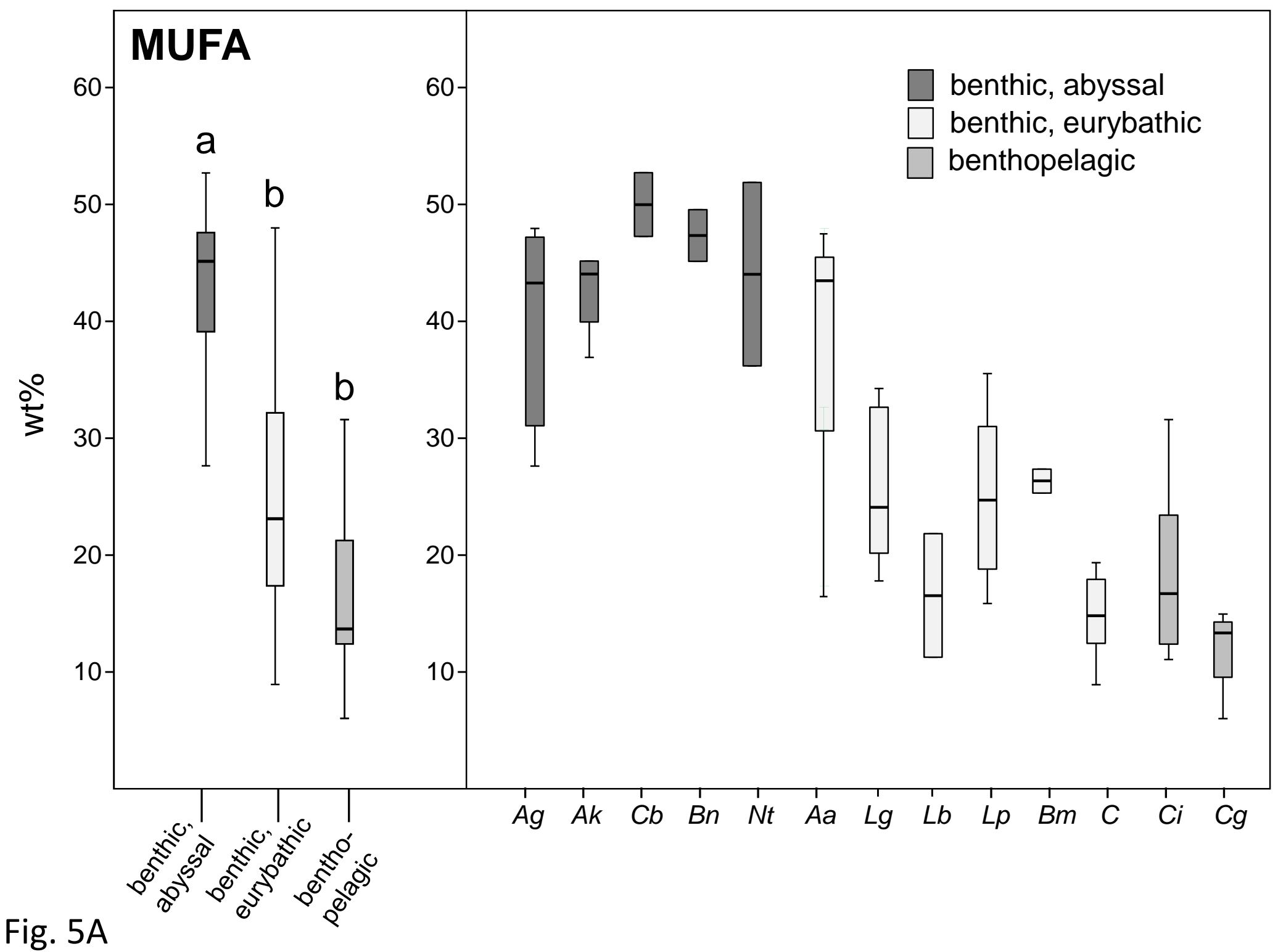


Radnaeva et al.

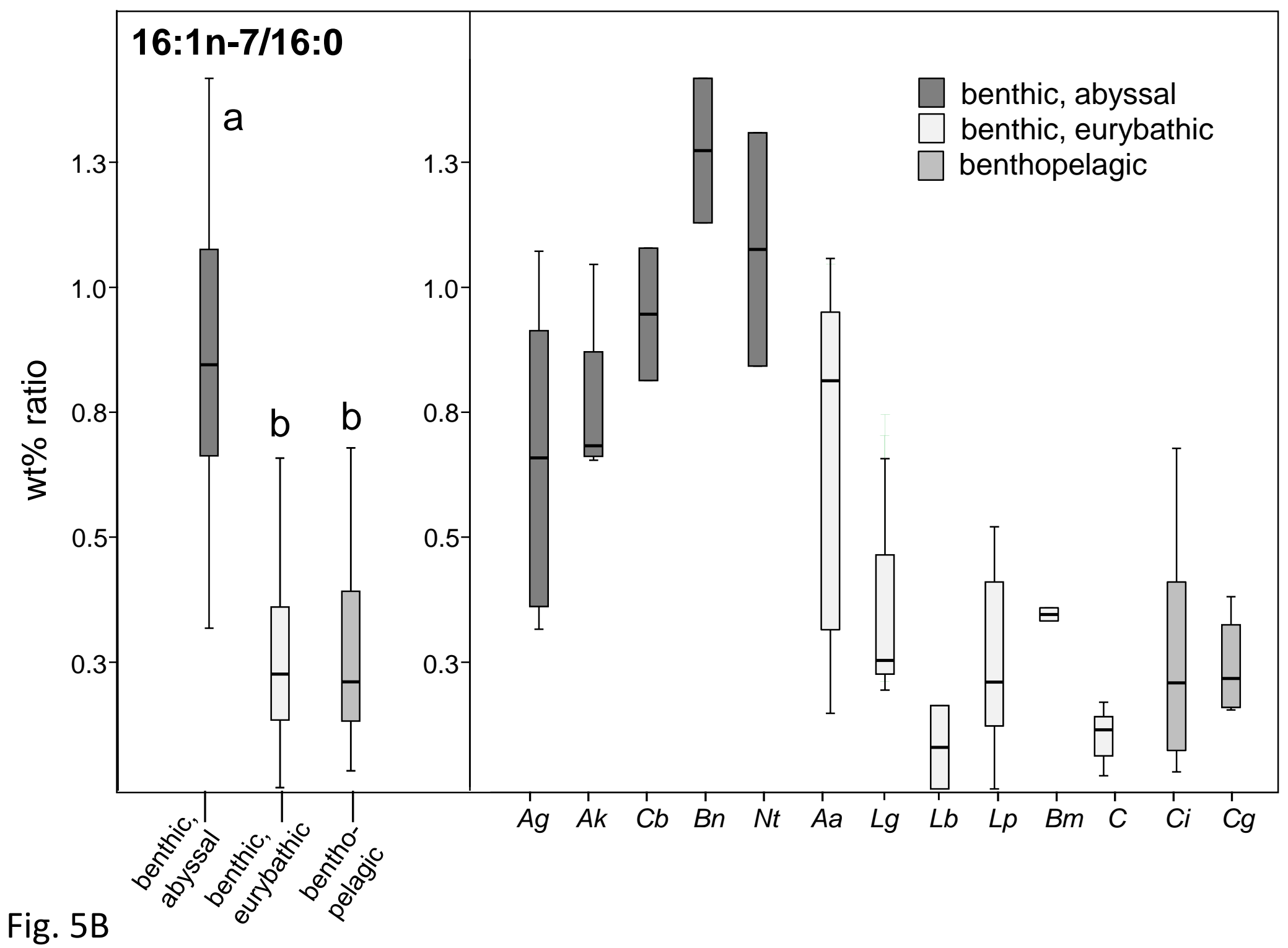


Radnaeva et al.

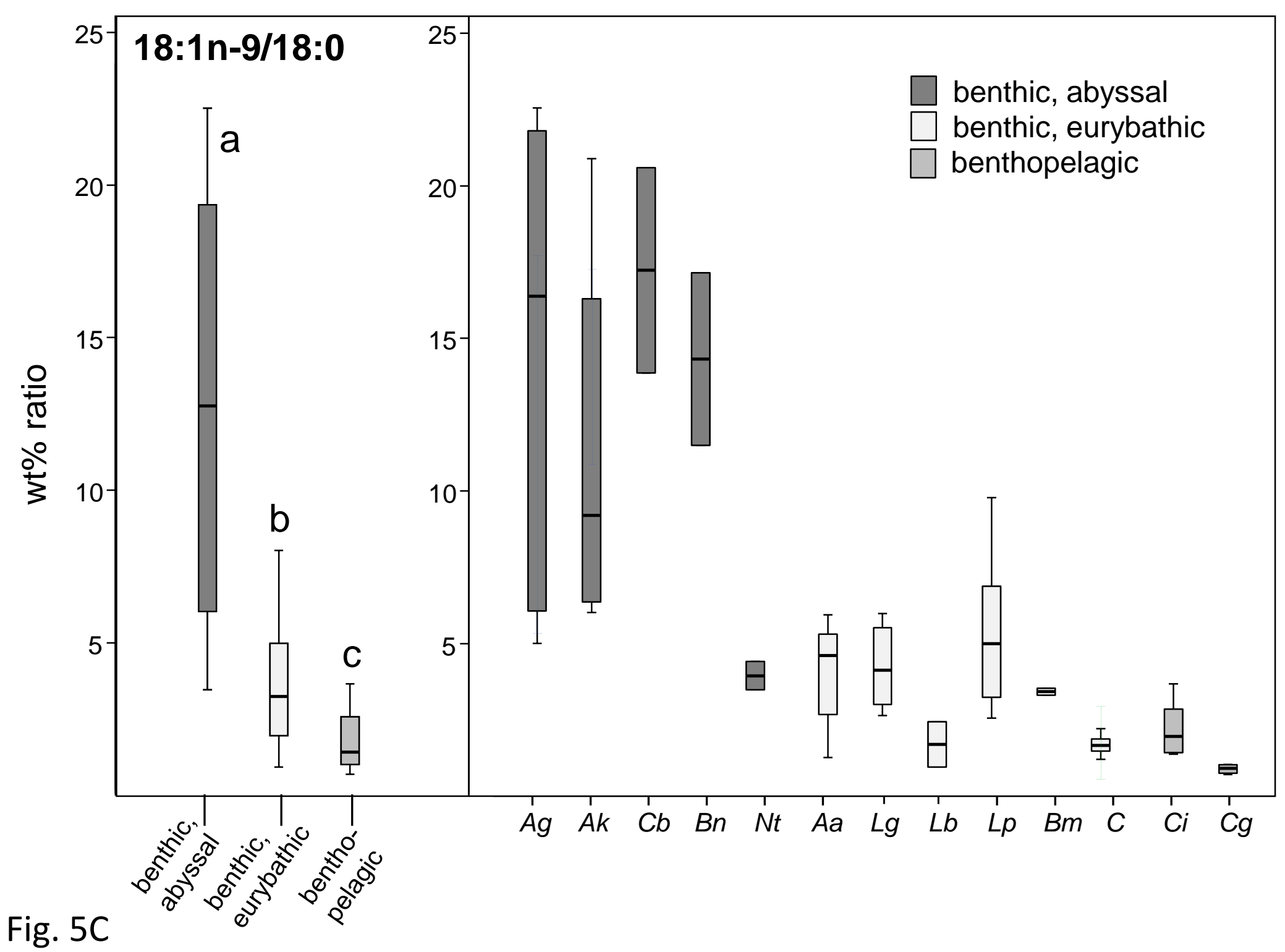


Radnaeva et al.

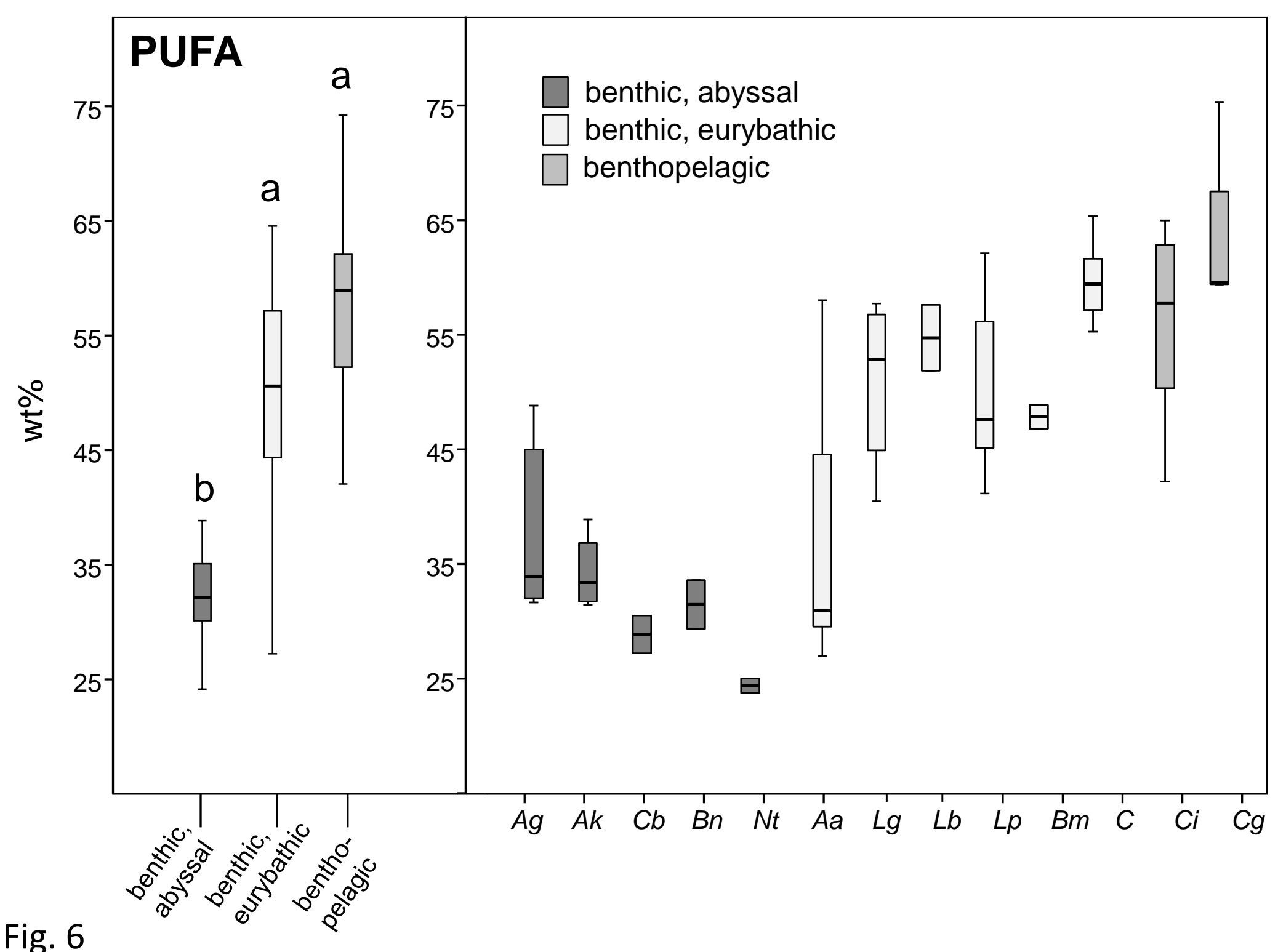




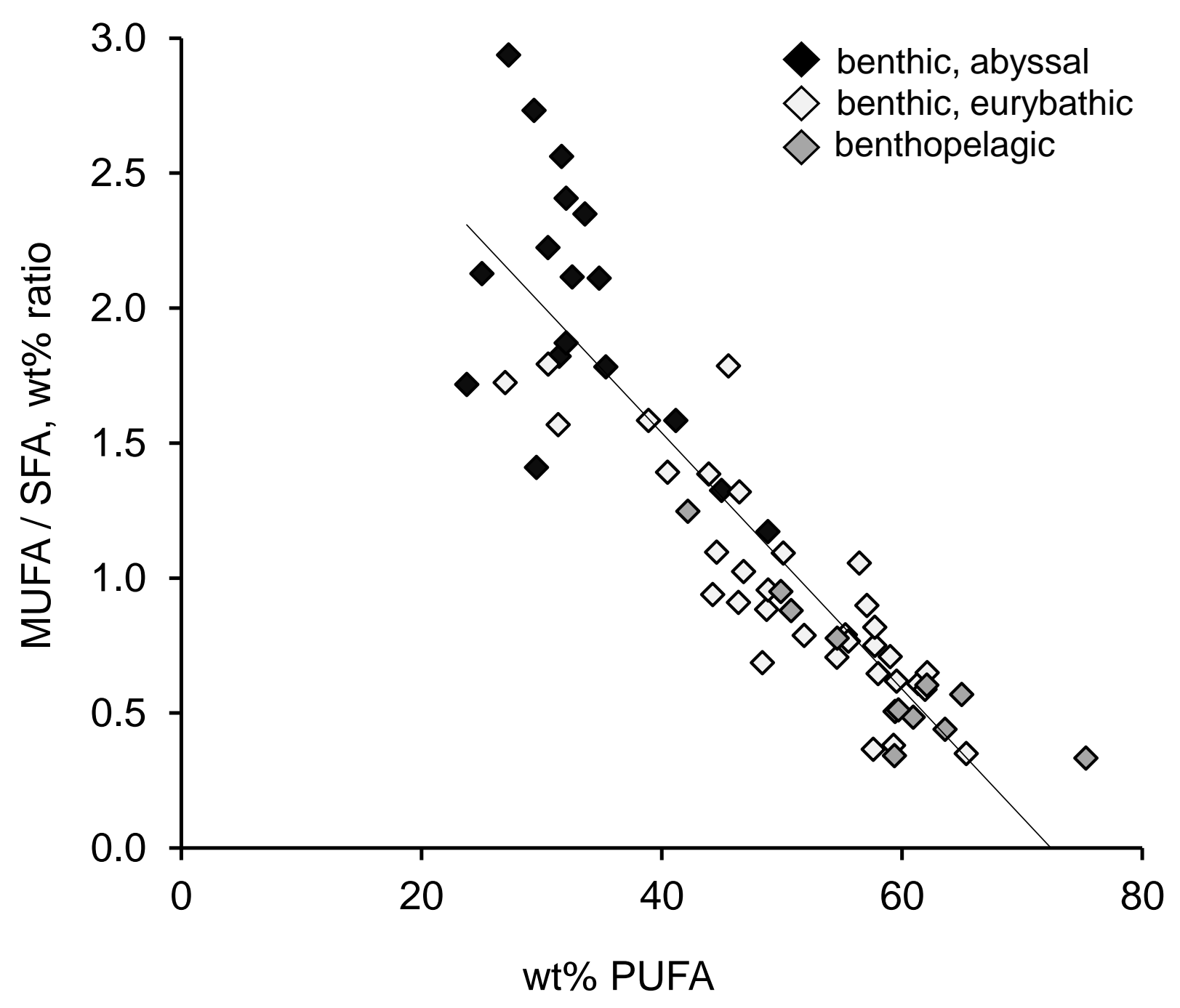

Fig. 7 
Radnaeva et al.

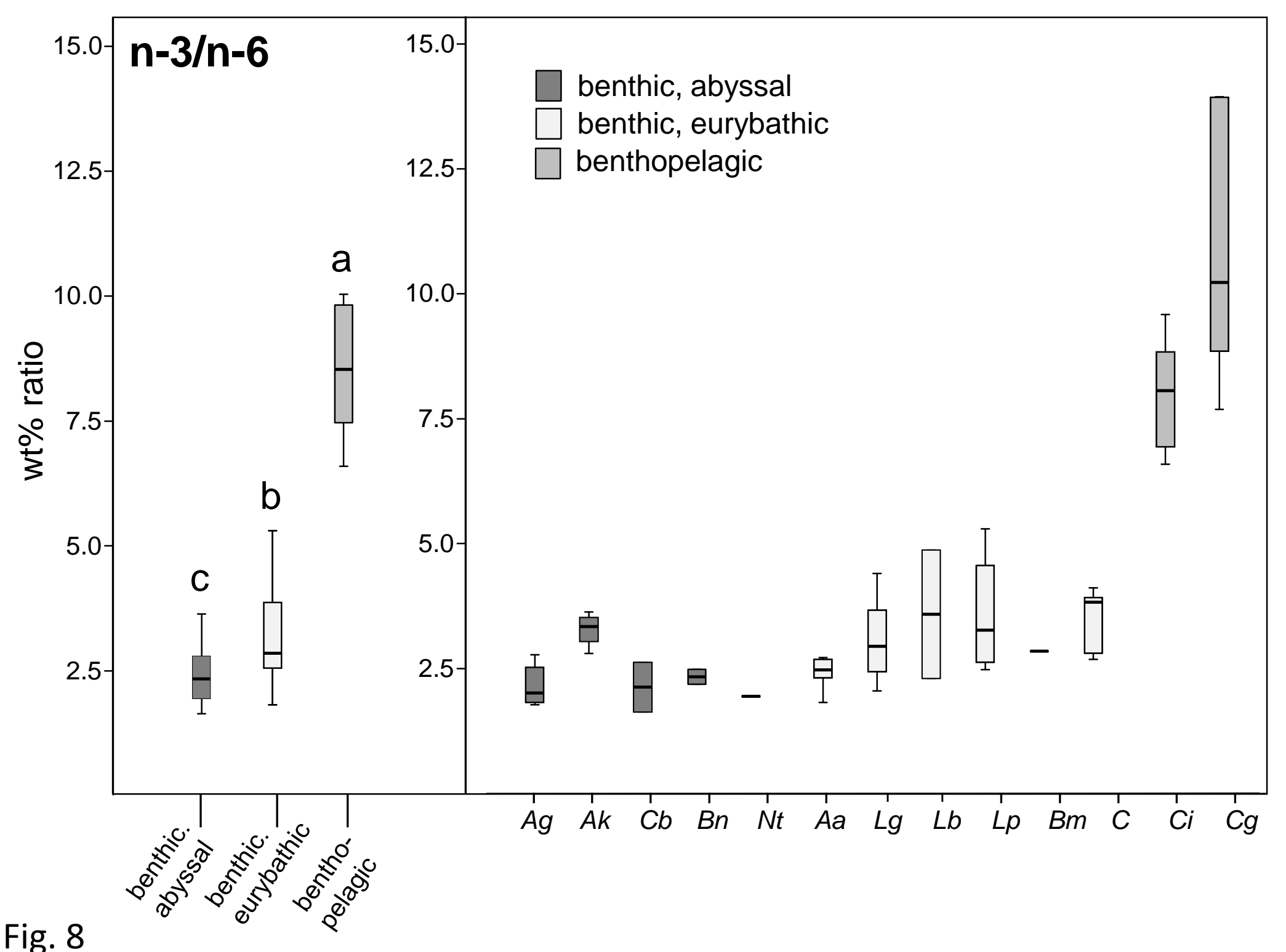


Click here to access/download Supplementary Material RAS statement to Transfer Desk.pdf 